\title{
U⿱宀⿻三丨口
}

\section{Nanoneuromedicine for management of neurodegenerative disorder}

Dwivedi, N., Shah, J., Mishra, V., Tambuwala, M. M., \& Kesharwani, P. (2018). Nanoneuromedicine for management of neurodegenerative disorder. Journal of Drug Delivery Science and Technology, 49, 477-490.

Link to publication record in Ulster University Research Portal

Published in:

Journal of Drug Delivery Science and Technology

Publication Status:

Published online: 21/12/2018

\section{Document Version}

Publisher's PDF, also known as Version of record

\section{General rights}

Copyright for the publications made accessible via Ulster University's Research Portal is retained by the author(s) and / or other copyright owners and it is a condition of accessing these publications that users recognise and abide by the legal requirements associated with these rights.

\section{Take down policy}

The Research Portal is Ulster University's institutional repository that provides access to Ulster's research outputs. Every effort has been made to ensure that content in the Research Portal does not infringe any person's rights, or applicable UK laws. If you discover content in the Research Portal that you believe breaches copyright or violates any law, please contact pure-support@ulster.ac.uk. 


\title{
Nanoneuromedicine for management of neurodegenerative disorder
}

\author{
Nitin Dwivedi $^{\mathrm{a}}$, Jigna Shah ${ }^{\mathrm{a}}$, Vijay Mishra ${ }^{\mathrm{b}}$, Murtaza Tambuwala ${ }^{\mathrm{c}}$, Prashant Kesharwani ${ }^{\mathrm{d}, *}$ \\ a Pharmacology Research Laboratory, Institute of Pharmacy, Nirma University, Ahmedabad, Gujarat, 382481, India \\ ${ }^{\mathrm{b}}$ School of Pharmaceutical Sciences, Lovely Professional University, Phagwara, Punjab, 144411, India \\ ${ }^{\mathrm{c}}$ School of Pharmacy and Pharmaceutical Sciences, Saad Centre for Pharmacy and Diabetes, Ulster University, Cromore Road, Coleraine, Co. Londonderry BT52 1SA, \\ United Kingdom \\ ${ }^{\mathrm{d}}$ Department of Pharmaceutics, School of Pharmaceutical Education and Research, Jamia Hamdard, New Delhi, India
}

\section{A R T I C L E I N F O}

\section{Keywords:}

Neurodegenerative disorder

Parkinson disease

Nanotechnology

Alzheimer

\begin{abstract}
A B S T R A C T
Conventional drug delivery systems are inadequate in providing essential cyto-architecture restoration and connection patterns because of restrictions posed by the restrictive blood-brain barrier. Nanotechnological approaches involve various nano-sized carrier systems and other devices, which stimulate the action of therapeutic agents on molecular level and revolutionized the treatment and diagnosis of neurodegenerative disorders with minimal side effects. Over the conventional approaches, nanotechnological approaches have various promising strategies to cross blood brain barrier and increase the bioavailability of therapeutics in brain. This review article emphasizes the current and future utility of nano drug delivery systems for the treatment of various neurodegenerative disorders.
\end{abstract}

\section{Introduction}

Neurodegenerative disorders (NDs) inscribe the progressive damage of neurons, usually concerned with death of neuronal cells. Various types of NDs like Alzheimer's (AD), Parkinson's (PD), Prion (PrD) disease and Amyotrophic Lateral Sclerosis (ALS) are associated with the neuronal damage in the different areas of brain and spinal cord. At present the available diagnosis and treatment strategies for NDs are inadequate to inhibit the progression of the brain injury or degeneration. The blood-brain barrier (BBB) appeared as one of the most arduous hurdles for the transport of therapeutic or imaging contrast agent into the nervous system [1-4]. While the available potentials for imaging and therapy of brain disorders mostly depend on the vascular and penetration ability across the BBB [5-7], for the rectification of these problems, a novel, safe and more sensitive imaging modality with improved therapeutic potential is immediately required. The nanoneuromedicine offer innovative and promising approaches to address the NDs as well as other nervous system diseases for which limited options are available [8].

Theranostics, the nanotechnology-based devices, have ability to deliver therapeutic, imaging and diagnostic agents at a time [9]. However current practices of nanotechnology in pharmaceutical field have been represented in Fig. 1Aand B. Nanomedicine and other related technologies improve transportation of biological active/imaging/contrast agents from the BBB; increase the drug-carrier bond with clearance of pathogens from nervous system [10]. At present various types of nanomaterials are available with different physicochemical and therapeutic properties. The nanomedicines have tremendous positive features like greater chemical or biological substantiality, incorporating capability for hydrophilic as well as hydrophobic molecules, can be used in the treatment or diagnosis of various NDs (Table 1). In addition, the nanomedicines can administer from several routes like olfactory, oral and systemic etc. This review highlights variety of features of nano technological approaches involved in the treatment and prognosis of various NDs.

\subsection{Latest developments in nanotechnology, nanomaterials and nanoarchitectonics}

Recently, in the field of nanomedicine Li et al. developed layer-bylayer self-assembled stacked Testudo-like MoS2-NS superstructures carrying doxorubicin (Dox) and DNA oligonucleotides, which was considered as a base platform, achieving high efficacy and autonomous ATP responsive drug delivery $[11,12]$.

Single walled carbon nanohorns (CNHs) are graphene-based tubules having $25 \mathrm{~nm}$ diameter and $4050 \mathrm{~nm}$ length. In medical field, their potential uses are in drug delivery, diagnosis, and clinical tests. Nakamura et al. developed micelles based drug delivery system by dispersing $\mathrm{CNH}$ in phospholipid poly(ethylene glycol) (PLPEG) and revealed the effect of PLPEG quantity on the cytotoxicity of PLPEG-CNH

\footnotetext{
* Corresponding author.

E-mail addresses: prashantdops@gmail.com, prashant_pharmacy04@rediffmail.com (P. Kesharwani).
} 


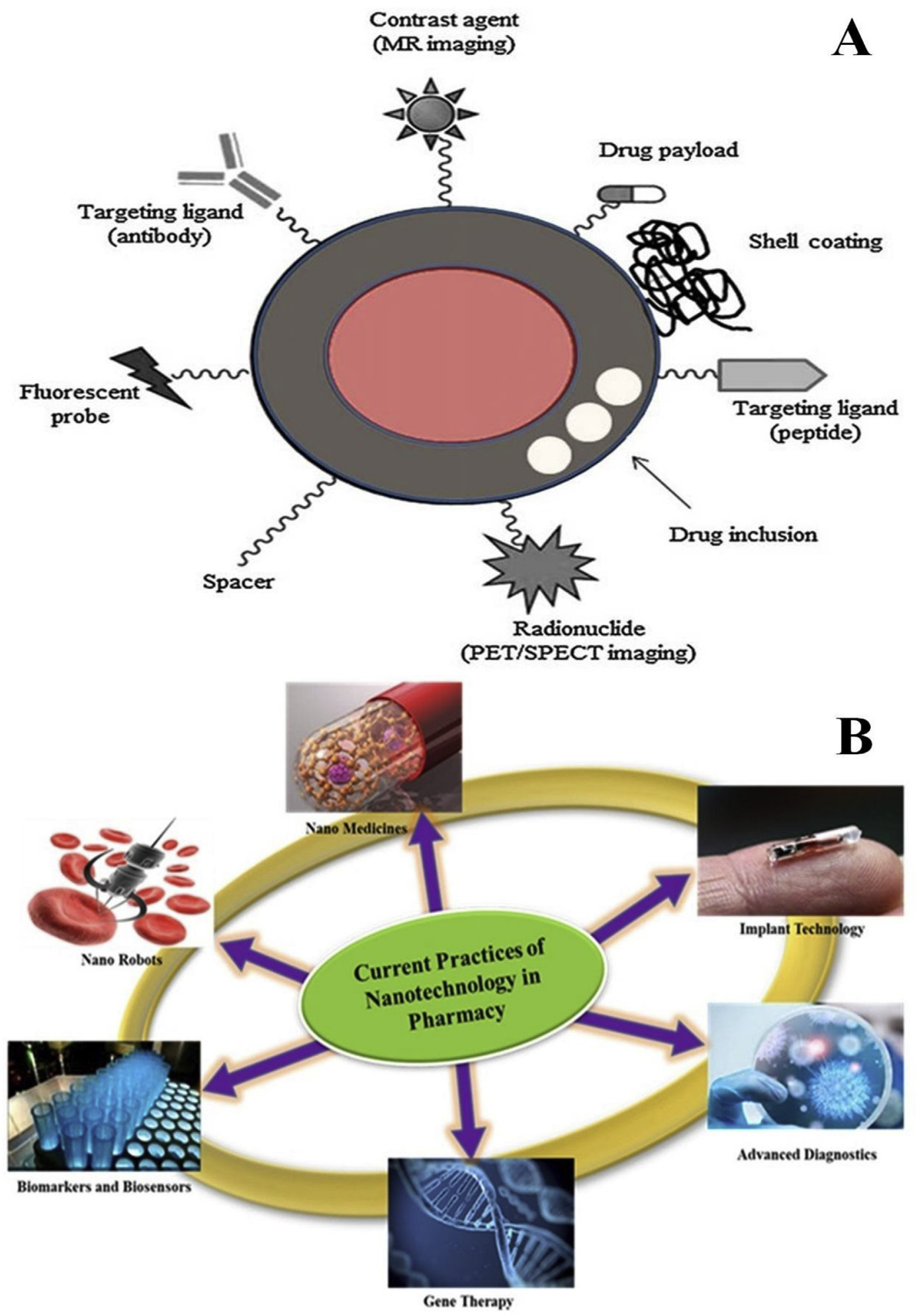

Fig. 1. (A) Graphical representation of theranostics system; (B) Current application of theranostics nanotechnology in pharmaceutical field.

in RAW264.7 mouse macrophages. The optimum PLPEG:CNH weight ratio was found to be $0.5: 1$ and $1: 1$. At the higher or lower ratios, the PLPEG-CNH toxicity and the macrophage uptake quantity increased and large agglomerates appeared [13].

Carbon nanotubes (CNTs), one of the emerging members of carbon family are potentially used in sensing, bone scaffolds, drug and gene delivery, composite materials, and water purification. The credit for successful applications of CNTs goes to desired conductivity, specificity, selectivity, high aspect ratio, high porosity and loading, ease in surface modification, and non-toxicity [14].

Radioisotopes are frequently used for various medical applications. Nowadays, a considerable quantity of ${ }^{99 \mathrm{~m}} \mathrm{Tc}$ is generated in hospital using ${ }^{99} \mathrm{Mo} /{ }^{99 \mathrm{~m}} \mathrm{Tc}$ generators. In this regard, Saptiama et al. prepared mesoporous alumina (MA) materials as potential adsorbents for molybdenum (Mo) using a soft-templated method. The change in calcination temperature from 600 to $900{ }^{\circ} \mathrm{C}$ improved the crystallinity but 


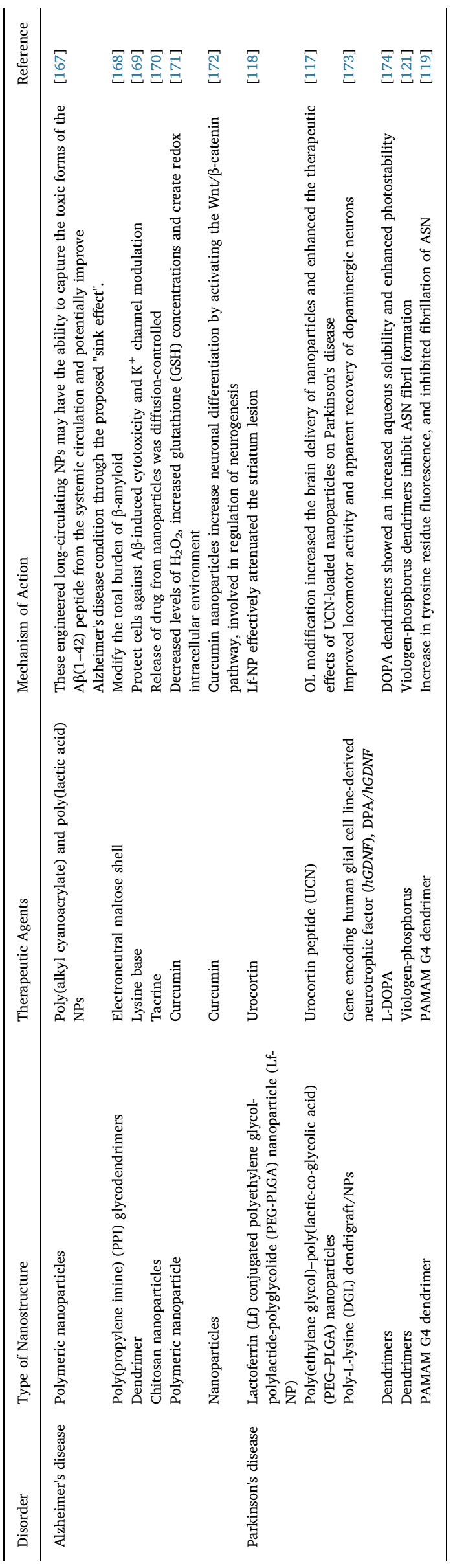

decreased the surface area and the pore volume of the MA materials. These results can guide the design of effective Mo adsorbents based on mesoporous materials toward ${ }^{99} \mathrm{Mo} /{ }^{99 \mathrm{~m}} \mathrm{Tc}$ generator preparation [15].

Nanoarchitectonics involves architecting of materials in the nanoscale. There are two types of bio-related nanoarchitectonics i.e. DNA nanoarchitectonics and cell macromolecular nanoarchitectonics. The former involves functionalization of single DNAs by chemical method to achieve stronger DNA binding, DNA aptamers and DNAzymes. Programmable assemblies of DNAs find their applications for selective labeling of biomaterials in cells and in animals, delivery of drugs to target sites and sensing in vivo. The later involves the construction of highly organized synthetic/natural macromolecular modified hybrid biointerfaces [16,17].

\section{Nanotechnology across the BBB}

The BBB is a physical and biological occlusion present in amid of central nervous system (CNS) and systemic blood circulation, protects brain from unwanted substances and other intruders [18]. The BBB contains endothelial cells, smooth muscle cells, pericytes, microglial cells and astrocytes with a tight junction amongst them and restrict the transcellular flux (Fig. 2A) [19-21]. Currently, nanotechnology appears as promising strategy in which the nanomaterials interact with BBB at molecular level and transport across the BBB through existing mechanisms (Fig. 2B) [20,22], without any intervention in the usual function of BBB and itself [23]. The nanomaterials have transcellular movement from blood to brain across the BBB with transcytosis movement involve receptor as well as adsorption mediated mechanism [24]. To achieve brain targeting across the BBB, the nanomaterials must have many competencies like minimum surface area, prolonged halflife in blood, nontoxic, biodegradable, biocompatibility, non-inflammatory and non-immunogenic with avoidance of reticulo-endothelial system (Table 2) [25-29]. The vital features of nanomaterials are depicted in Fig. 3.

\subsection{Adsorptive-mediated transcytosis}

Adsorptive-mediated transcytosis lead to electrostatic interaction of a ligand with the luminal surface charges of endothelial cells. The fabrication cell penetration peptides (e.g. TAT-derived peptides) and cationic proteins (e.g. albumin) on the surface of nanomaterials facilitate the passage across the BBB [24,30]. Thus, the addition of different domains like glycosylation [31], methylation [32] PEGylation [33-38], lipophilic domains $[39,40]$, virus glycoprotein [41,42] or coating with polysorbates [24] on the surface of different types of nano devices lead to an enhanced penetration potential across the BBB. The diffusivity of nano devices across the $\mathrm{BBB}$, several times depends on the material used in the coating, charge of the surface and the matrix of these particulate systems. An albumin coating, reduce the interaction between extracellular space proteins and decrease the size effect on the distribution of nanospheres $[40,43]$. Thus, these nanocarriers have greater optimization in convection enhanced delivery (CED) [42,44].

\subsection{Receptor-mediated transcytosis}

Receptor mediated transcytosis is more intensively explored physiological procedure. This involves the transportation of various nanomaterials across the BBB based on affinity towards the receptors of BBB cells. Receptor mediated transcytosis is achieved by addition of some specific proteins such as insulin [45], transferrin [46], apolipoprotein $[47,48]$, macro-globins and other small peptides that are able to act as ligands for the receptors located on cells of BBB.

Certain monoclonal antibodies (mAbs) undergo receptor mediated transcytosis and are directed towards the receptors on BBB. Like the binding of OX26,8D3 \& R17217 mAbs with transferrin, receptors recognize different epitopes and avert the competition with innate 

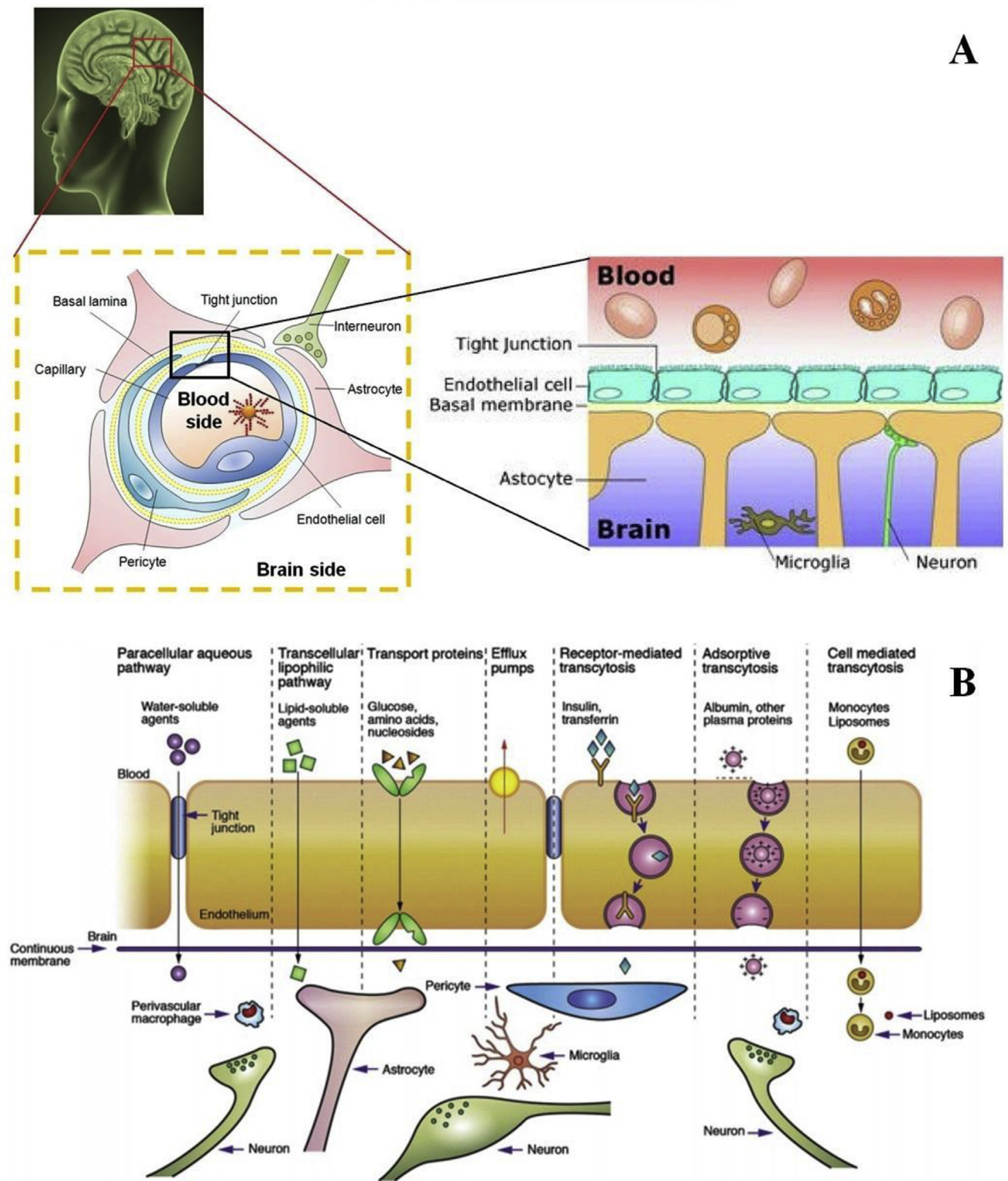

Fig. 2. (A) An insight of blood brain barrier (BBB); (B) Schematic representation of different transport pathways across the BBB [166].

transferrin in blood [49]. On the other hand, some mAbs involved in construction of brain targeted drug delivery devices are directed against insulin receptors [50].

\section{Nanotechnology for AD}

Literature suggests that $\mathrm{AD}$ affects more than 24 million people worldwide. Alzheimer's disease lead to onward loss or deterioration of neurons of cortical and hippocampal leads to memory and cognitive dysfunction [51]. Another neuropathological hallmark of AD is appearance of neurofibrillary tangles containing hyper-phosphorylated tau protein on intraneuronal paired helical filaments and extracellular plaques of $\beta$ amyloid peptide (A $\beta$ ). $A \beta$ are small fragments of amyloid precursor proteins (APP) containing 39-43 amino acids. Thus, the aggregation of small segments of $A \beta$ (ADDLs, amyloid- $\beta$-derived diffusible ligands) are mainly responsible for memory deficits and synaptic damage in $\mathrm{AD}[52,53]$.

\section{1. $A D$ therapy}

At present, the available therapies of $\mathrm{AD}$ are based on cholinergic progress, particularly on the cholinesterase (AChE and BChE) activities prohibition [54]. Although cholinergic inhibitors have greatest benefit for cognitive dysfunction, these are unable to compensate the continuous loss of hippocampal and cortical neurons. Currently the treatment of $\mathrm{AD}$ depends on acetylcholinesterase (AChE) inhibitors (Rivastigmine, Dopenezil, Galantamine) or NMDAR inhibitor (Memantine) indicate only momentary effect but unable to stop disease progress and mainly administered orally or transdermally [55-57].

In year 2000, Rivastigmine, a non-competitive and reversible AChE 


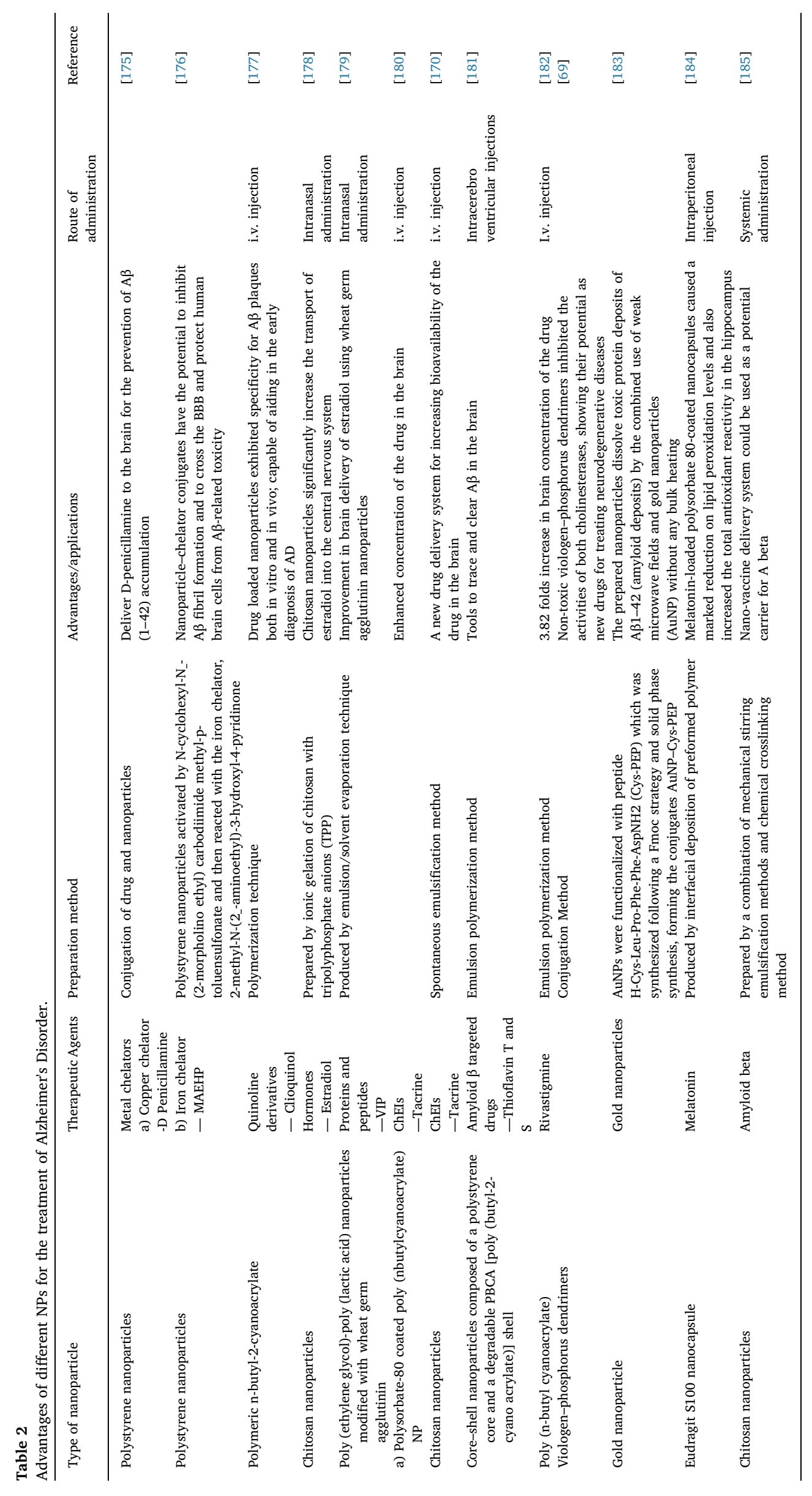




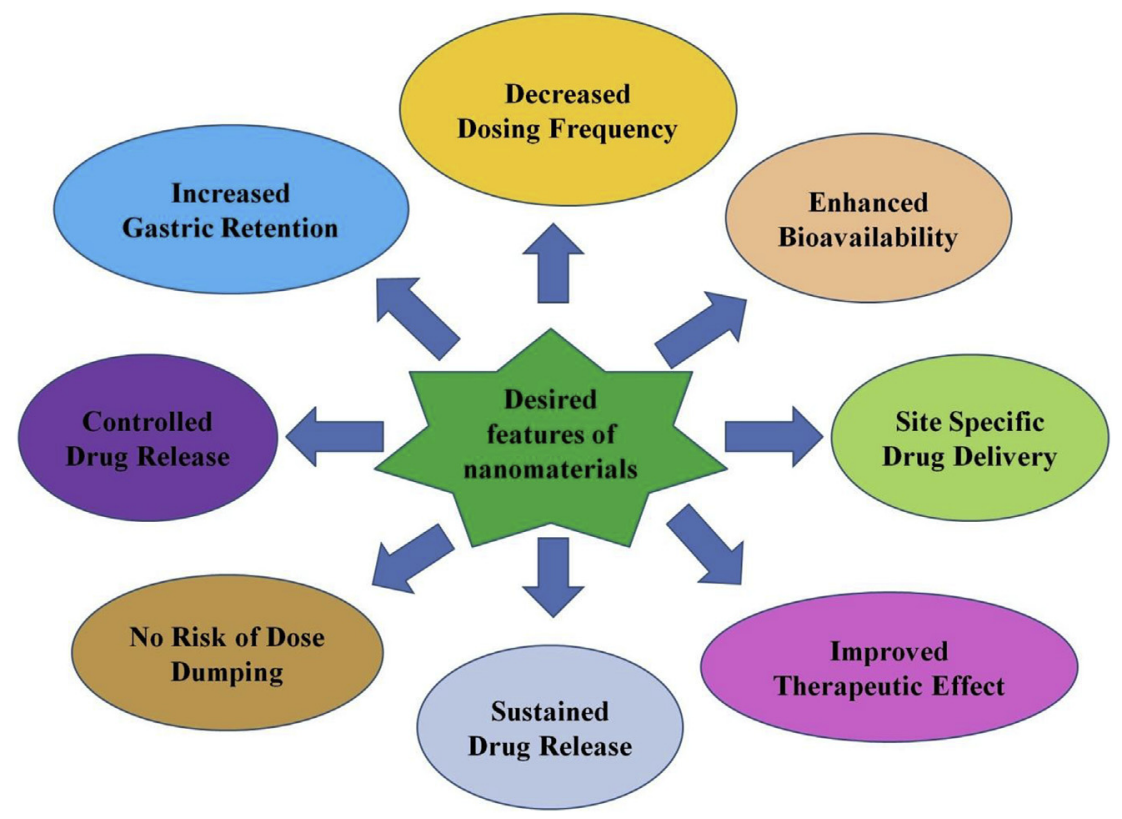

Fig. 3. Desired features of nanomaterials.

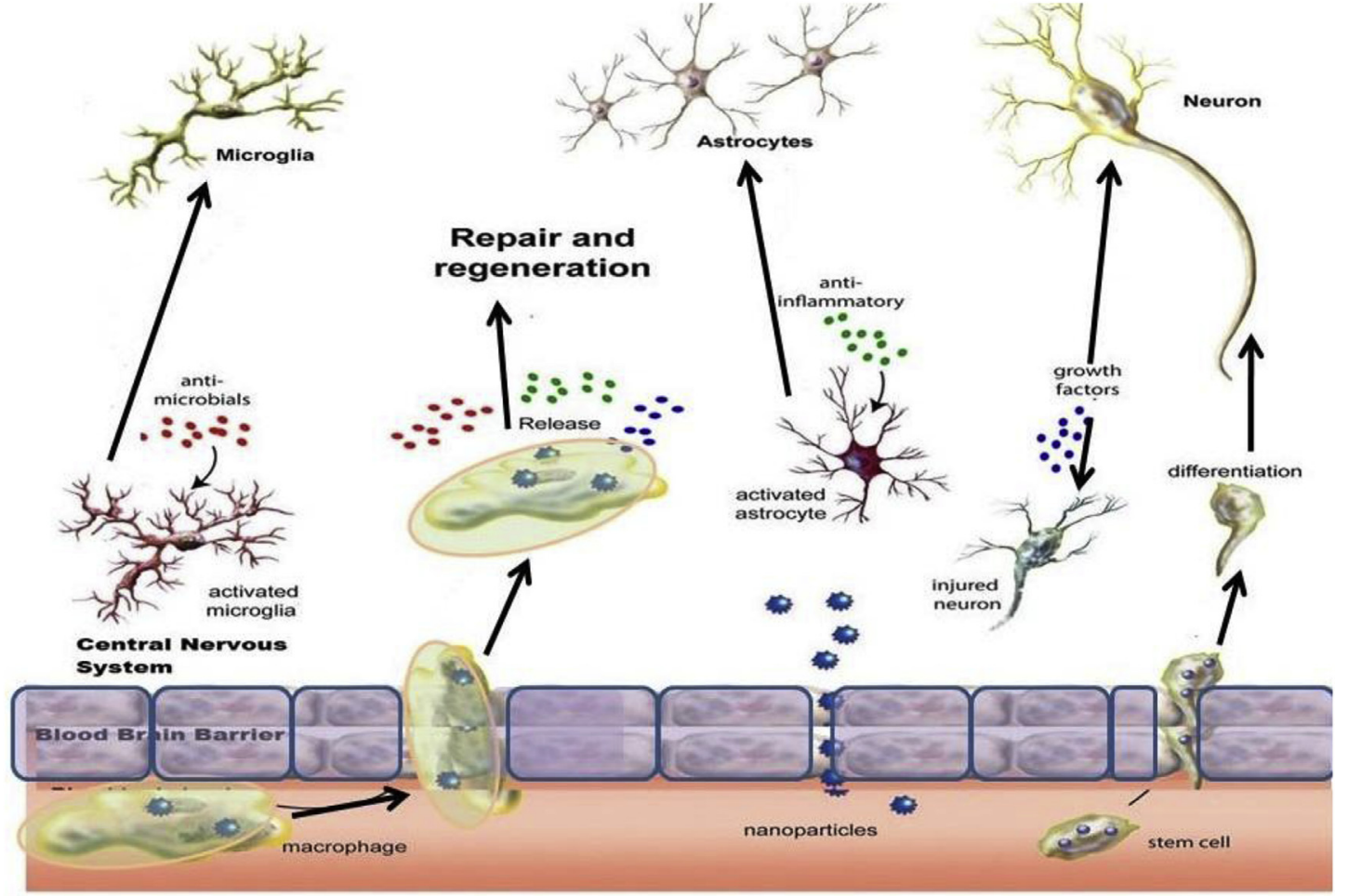

Fig. 4. Pictorial representation of treatment of neuro-diseases from nanomedicine.

inhibitor was approved by the FDA for the treatment of AD [58]. Now a day, nanotechnological strategies are employed for enhancing the potency of $\mathrm{AD}$ therapies (Fig. 4). The nanotechnological devices target to A $\beta$ aggregation and fragmentation of APP, not only in CNS even in blood with the approach of reducing its level in brain [59]. The reduction of $A \beta$ aggregation and fragmentation of APP in the brain is known as 'sink effect'. Gobbi et al. developed nanoliposomes (NLs) utilizing phosphatidic acid or cardiolipin [60]. In an another study it has been observed that these NLs have greater affinity towards $A \beta$ and diminished the toxicity of these peptides in ex-vivo condition [61]. Canovi et al. developed NL formulation with anti-A $\beta$ mAb, indicating higher affinity for $\mathrm{A} \beta$ in ex-vivo as well as in vivo studies [62]. In addition to these, Mourtas et al. developed another formulation of NL with curcumin derivative, which displayed high affinity towards $A \beta$ and inhibited $A \beta$ aggregation in an in vitro model $[63,64]$.

Amyloid fibrillar deposition of misfolded proteins can be exploited for both therapy and diagnosis of AD. Recently, Orteca et al. developed structurally modified curcumin (phtalimmide derivative, K2F21) scaffold for improving its bioavailability, pharmacokinetic stability in physiological conditions, and in vitro ability to interfere with $\beta$-amyloid fibrils and aggregates at different incubation time. Computational simulations established the modification in conformational dynamics and 
interaction with the amyloidogenic region of the protofibril facilitating disaggregation on ligand binding. In vitro results reflected safety and protection against glutamate toxicity in hippocampal HT-22 mouse cells at $1 \mu \mathrm{M}$ concentration. Authors claimed that the developed derivative of curcumin appeared as a promising candidate for both diagnosis and therapy of AD [65].

On the other hand, dendrimers are appeared as one of the most successful tools for the management of neurodegeneration at the nanoscale level. Dendrimers have greater capability for crossing BBB and targeted drug delivery with low toxicity [66], thus dendrimers emerge out as interesting device in treatment of NDs. It has been observed that PAMAM and phosphorus dendrimers indicated their anti-amyloidogenic activity $[67,68]$. Cieplucha et al. reported potential of viologen-phosphorus dendrimer for the inhibition of AChE and BChE activities and showed its caliber against AD [69]. Klajnertet al. investigated effect of 27 terminal morpholine fabricated GATG (gallic acid-triethylene glycol) dendrimer on the aggregation process of $A \beta$ peptides. The developed formulation reduced the amount of prefibrillar forms of $A \beta$ and ultimately lowered the toxicity of $A \beta$ peptides [70].

On the other side, the available literature indicated the promising therapeutic potential of various growth factors and neurotrophins against the AD [71-74]. Growth factors (GFs) like insulin-like growth factor (IGF-1/IGF-2) [75,76], bone morphogenetic proteins (BMPs) $[71,77,78]$, basic fibroblast growth factor (bFGF) [79-81] and glialderived neurotrophic factor, GDNF [82], neurotrophins (nerve growth factors, NGF) [83-85]; and brain-derived neurotrophic factor (BDNF) $[86,87]$ are very hopeful therapeutic molecules for the management of NDs. Lauzon et al. discussed various strategies involving specificity enhancement of growth factors (GFs) to brain and provided information regarding recent advancement for brain targeted delivery of GFs in term of in-vivo and in-vitro effect in context of $\mathrm{AD}$ [88]. For the treatment of $\mathrm{AD}$, Yang et al. developed single-walled carbon nanotubes (SWCNTs), which successfully delivered acetylcholine into brain then SWCNTs easily entered into lysosomes and reached to targeted organelles, except mitochondria [89].

Metals like copper, zinc, iron, and aluminum promoted oxidative damage is one of the causes of AD. FDA approved D-Penicillamine, a copper chelator to treat AD. The D-penicillamine decreases the amount of metal ions, which promote the beta-amyloid deposition in $\mathrm{AD}$ patients. Further, it does not affect the integrity of the BBB [90].

\subsection{AD diagnosis}

Nanotechnology attempt more lucrative methods over conventional assays for the estimation of amyloid-beta derived diffusible ligands or tau protein (pathogenic markers) in human CSF employed in early invitro diagnosis of $\mathrm{AD}$ [91]. In this context, nanotechnology indicate tremendous advantage for effective imaging of CNS functions and status of diseases as well as in advance neuro surgical practices. Now a day, Magnetic Resonance Imaging (MRI) has appeared as the vital tool for the imaging of brain disorders. Positron Emission Tomography (PET) imaging also very potent in diagnosis of the various nervous system disorder's mechanisms, including the pathophysiology of AD. In this course, radio-labeled amyloid ligands tracked the pathophysiological process of AD [92-94].

Gadolinium, iron and manganese containing nanoparticles (NPs) are extensively explored for their contrast activity. Among them superparamagnetic iron oxide (SPIO) NPs have greater surface area, magnetic properties with low toxicity, create more interest in this approach. Generally, core of SPIO NPs contains a crystalline iron oxide (including magnetite, $\mathrm{Fe}_{3} \mathrm{O}_{4}$, or maghemite, $\gamma \mathrm{Fe}_{2} \mathrm{O}_{3}$ ), which make it biocompatible and encased in a coated monomerous polymer $[95,96]$. The ferumoxtran-10 (dextran coated USPIO) involved in the diagnosis of ischemic damage in patients of cerebral ischemia [97]. On the other hand, Beckmann et al. studied amyloid precursor protein mouse AD model for cerebral amyloid angiopathy and found that MRI detection of microvascular lesions in the brains of the mice was enhanced with the systemic administration of SPIOs. In case of AD, SPIO NPs s entered in the monocytes and traveled into the circulation then penetrate in the brain through chemokines due to attraction of amyloid beta (A $\beta$ )-stimulated glial cells [98].

The clinical MRI agents like Feridex (Endorem) and Resovist ${ }^{\circ}$ were used as important tool for diagnosis of AD. The AMAG Pharma discontinued Feridex ${ }^{\circ}$ in 2008, whereas in 2001, Resovist ${ }^{\circ}$ was approved for the European market, but in 2009 its production was abdicated. Thus, essentially, a clinically active device for screening of AD should be available in the market. Li et al. reviewed various nano-approaches involved in the generation of MRI contrast agents for cell labeling and tracking [99]. Polyethyleneglycol (PEG)-coated USPIO NPs may adhere with A $31-42$ peptides and offer a wide opportunity for simultaneous targeting and imaging of amyloid plaques in $\mathrm{AD}$ transgenic mice. Thus, intravenous injection of these NPs transiently opens the BBB for detection of the level of amyloid plaques [100]. On the other hand, ultrasensitive immunosensors involve surface plasmon resonance for the detection of A $\beta$ peptides [101]. While scanning tunneling microscopy utilize specific immobilized $\mathrm{mAb}$ fragments on the surface of gold nanoparticles ( $\mathrm{Au}$ NPs) for recognition and lead to electrical detection [102]. Yang et al. synthesized and marked out $A \beta-40$ or $A \beta-42$ antibodies coated with some specific SPIO and applied them in the immunoassay of AD [102]. Neely et al. developed and characterized antitau antibodies coated Au NPs involved in two-photon Rayleigh scattering assay for the detection of CSF tau proteins [103].

Moreover, in the clinical diagnosis $A \beta-40$ or $A \beta-42$ peptides levels involve a comparative estimation of these peptides in normal and $\mathrm{AD}$ patients. The $A \beta$ screening methods involved electrochemical sensing of saccharide-protein interactions, has also been reported [104]. In addition, with this context, Georganopoulou et al. have established ultrasensitive assay [105], for the determination of approximate ADDL concentration by utilizing Au NP bio-barcode. for the detection of tau protein, While Neely et al. [103] utilized photons coupled antibody coated $\mathrm{Au}$ NP. Recently, nano-HPLC-MS technologies also have been used as possible additional pathogenic marker of AD and are involved in phospholipid profiling of CSF, providing an opportunity to follow lipid changes [106]. On the other hand, streptavidin conjugated quantum dots (QDs) indicated a high sensitivity for the recognition of AAP for the in-vitro estimation in comparison with conventional fluoro immunoassay [107].

While in-vivo nanotechnological approaches involve the estimation of $A \beta$ deposits in the brain, the deposition of $\beta$ amyloid protein in $A D$ transgenic mice was detected from $\mu$ MRI technique which involved A $\beta$ coupled iron oxide NP either superparamagnetic or mono crystalline form [108]. Roney et al. synthesized polymeric n-butyl-2-cyanoacrylate $\mathrm{NP}$ enclosed with the radio-labeled drug ${ }^{125} \mathrm{I}-\mathrm{CQ}$ which has affinity towards amyloid proteins [109]. The obtained results indicated the BBB crossing ability of NP with rapid transportation and retention in the AD transgenic mice brain in comparison of controls.

\section{Nanotechnology for Parkinson's disease}

PD lead a progressive loss of neurons of specific areas of brain approximately $1-2 \%$ of the population of age $\leq 65$ years is affected from PD disorder in the world [110]. PD involve the loss of dopaminergic neurons in the substantia nigra and pars compacta and results of difficulties in the movement control. The appearance of Lewy's bodies in the brain of PD patients is the primary sign of this disorder. The Lewy's bodies contain $50-700 \mathrm{~nm}$ long filaments of the $\alpha$-synuclein proteins as cytoplasmic inclusions. Various cellular mechanisms such as ER stress, proteasomal and mitochondrial dysfunction are behind of neuronal death in PD [111]. 


\subsection{PD therapy}

At present, very limited supportive care, management and cure is available for PD. All these situations slow down the treatment and therapy of PD and alleviate the progression of disease. The available pharmacological treatment and therapy mainly pay its attention on restoration of dopaminergic neurotransmission [112].

Nanotechnological approaches lead a safe and effective strategic resolution over the available conventional approaches for the best remedy of PD. Tiwari et al. synthesized nicotine-encapsulated poly(lacticco-glycolic)acid (PLGA) nanoparticles. At nanosize the bioavailability of nicotine enhanced with consequent decrease in the oxidative stress and apoptosis with an improved neuroprotective efficacy [113]. Recently Gerardo Leyva-Go'mez et al. presented an overview on technical aspects for drug delivery to the brain from the NPs. The study involve analysis of surface phenomena which are involved in functional development and synthesis of NPs for the treatment of PD [114]. Trapani et al. prepared specific chitosan NPs with an external DA coating. Invivo experiments on rats indicated that on intraperitoneal administration, DA loaded chitosan NP have less cytotoxicity with greater penetration to the striatum more than DA alone [115]. Huang et al. found a significant improvement in locomotor activity as well as minimization of dopaminergic neuronal loss, with the increase in DA levels in PD rat brain through the administration of human neurotrophic gene encapsulated in lactoferrin-modified NP [116]. In a study it has been observed that Odorranalectin (OL) NPs are act as potential carriers for the delivery of special macromolecular drugs from olfactory route to brain for the treatment of PD [117]. Hu et al. developed lactoferrin (Lf) conjugated polyethylene glycolpolylactide-polyglycolide (PEG-PLGA) nanoparticles (Lf-NPs) as a novel biodegradable brain drug delivery system, indicate auspicious drug delivery with less toxicity [118]. On the other side, various cationic dendrimers mark their candidature among the new pharmacological strategies against neurodegenerative disorders with the prevention of proteins fibrillation specially $\alpha$-synuclein fibrillation in the NDs [119-121]. Many times, dendrimers can also alter functions of different proteins i.e. viologen-phosphorus dendrimers modified the activities of AChE and BChE [122]. Recently, it has been investigated that carbosilane dendrimers prevented the $\alpha$-synuclein fibrillation for the rotenone-induced damage of hippocampal cells (mHippoE-18) in the rat brain. An another study indicated a broad contribution of dendrimers in the increased vitality, potentiation of mitochondrial membrane activity and decreased reactive oxygen species level in the cells of specific parts of the brain [123].

It has been found that exosomes from blood exhibit natural brain targeting ability by transferrin-transferrin receptor interaction. In this regard recently, Qu et al. developed dopamine loaded biocompatible, spherical blood exosomes of 40 and $200 \mathrm{~nm}$ size range for delivering drugs across the BBB. In vivo studies demonstrated that the blood exosomes successfully delivered dopamine to brain as witnessed by $>15$-fold increased dopamine brain distribution [Fig. 4]. Dopamine-loaded exosomes showed lower systemic toxicity as compared to free dopamine and improved therapeutic efficacy in a PD mouse model [124].

\subsection{PD diagnosis}

The clinical sign of PD include loss of more than $50 \%$ of the dopaminergic neurons and $75-80 \%$ of striatal dopamine in the brain [125-127]. Thus, PD must be detected in early stages for proper treatment. At this stage, the progression of PD can be easily suspended from the neuroprotective medicines, so the availability of a novel biomarkers for early detection of PD can help in its diagnosis and treatment [128,129]. Recently, Qiang et al. described clinical, neuroimaging, biochemical, genetic and proteomic biomarkers, which are involved in PD diagnosis and treatment. Single photon emission computerized tomography (SPECT), used for estimation of dopaminergic pathways in the brain may be useful to diagnose PD [130]. In a recent study, Akhtar and Stern, described early symptomatology of Parkinson's at-risk syndrome with the broad study of disease biomarkers and putative disease-modifying therapeutics used for PD. They compared clinical diagnosis, radiological screening and molecular examinations involved in the early detection of PD [131].

Now a days nanotechnological approaches possess their effectiveness in diagnosis and imaging of PD. In this sequence, An et al. tapped high sensitivity photo electrochemical immunosensor, Au-doped $\mathrm{TiO}_{2}$ nanotube (NT) arrays to trace $\alpha$-synuclein proteins in CNS [132]. Previously, Baron et al. developed Au NP with plasmon absorbance involved in an in-vitro quantitative estimation for neurotransmitters involved in PD pathology [133].

\section{Nanotechnology for prion disease (PrD)}

PrD lead to stockpiling of misfolded Prion Protein (PrP) isoforms, PrD included a bunch of NDs. First identified prion disease in human was Creutzfeldt-Jakob disease. It is found periodically and about one case per million individuals per year is observed. In the sane individuals, cellular isoform (PrPC) of prion protein exists two large alpha-helical structures. While in the pathogenic protease-resistant isoform (PrPSc), predominant $\beta$-sheet is found that may produce toxic amyloid aggregates. When a pathogenic isoform has been originated, PrPC modified into PrPSc via protein-protein interaction [134].

\subsection{Prion disease therapy}

Many in-vitro studies showed that different types of polyamine dendrimers are retracting pathogenic prion isoform (PrPSc) from lysosomal degradation and eradicate them from infected cells. The different polyamines have positive charges over them and their action depend on this positive charge. Lim et al. synthesized less toxic positively charged polyamines with greater potential [135]. Ai Tran et al. synthesized polyelectrolyte multilayer-coated Au NP containing sulfonates and primary amines as functional groups on the surface with a great therapeutic relevancy and inhibited to PrPSc aggregation in neuroblastoma cells at very low dose [136]. Sousa et al. [137] indicated that Au NP coated with the similar groups have crossing ability across the murine BBB and enter the specify neuronal structures in which PrP agglutination occurs. On the other side, McCarthy et al. on the bases of dendrimer/prion interactions, formulated a new working model which indicated that dendrimers destabilize the prion protein and rendering it susceptibility to proteolysis thus eliminate $\operatorname{PrP}(\mathrm{Sc})$ [138]. In another study, it has been found that dendrimers inhibited the intracellular conversion of PrPC to PrPSc while anti-prion activity is independent from their cationic surface charges. This work indicate inhibitory action of mPPI G5 dendrimers against the conversion of PrPC to PrPSc and also determine the effect of other drugs which are enhancing this action of mPPI G5 dendrimer [139].

\subsection{Prion disease diagnosis}

Xiao et al. developed a novel diagnostic approach, involving two different type of aptamers which were able to recognize various epitopes of PrPSc and segregate PrPSc from PrPc in serum as well as in brain homogenate [140]. In this approach, the aptamers were attached to the surface of QDs and magnetic micro particles, in presence of PrPSc. These produced a highly fluorescent sand which like structure in aqueous medium and it can be easily isolated under the influence of external magnetic field. Xie et al. demonstrated in-vitro site-specific labeling of PrP expressed on cell surfaces from PEG-interspersed nitrile triacetic acid-functionalized QDs [141]. 


\section{Nanotechnology for amyotrophic lateral sclerosis}

Amyotrophic Lateral Sclerosis (ALS) lead to fatal neurodegeneration and affect approximately $1-2 / 10,0000$ person per year. The signet of this disorder includes paralysis of voluntary muscles from the selective death of motor neurons in the brain and spinal cord. The mutations in SOD1 gene which encode superoxide dismutase enzyme is the main cause of ALS in approx. 20\% of familial ALS cases. The mutated SOD1 gene leads to formation of toxic free radicals and intracellular aggregates that restrict chaperone or proteasome activity, with consequent mis-folding and inadequate expulsion of manifold proteins [142].

For the specific treatment of ALS, Bondì et al. synthesized riluzole solid lipid NP with high drug loading capacity and a greater efficacy than free riluzole. The higher drug loading capability with greater carrying capacity of riluzole solid lipid NP into the brain with lower indiscriminate bio distribution in rats open an another route for the use of NP for ALS therapy [143].

Recently, a rat model of ALS detection involved administration of T cells labeled USPIO NP in the MRI technology. The study revealed an infiltration of $\mathrm{CD}^{+}$lymphocyte in the midbrain/interbrain, while $\mathrm{CD}^{+}$cells were more confined to the brainstem region [144]. Machtoub et al. for the detection of the pathological regions in ALS rat brain, injected USPIO NP conjugated with anti-CD4 antibodies from intravenous route [145].

\section{Nanotechnology for neuroprotection and neuronal tissue regeneration}

\subsection{Neuroprotection}

Most of the time, a higher level of reactive oxygen species is involved in CNS injuries. It has been observed that multiple radicals able to incorporate per-molecule similar as radical sponges, but a delocalized $\pi$ double bond system eradicate superoxide radicals over the dismutation catalytic mechanism [146]. A study indicated that a trismalonic acid derivative of the fullerene $\mathrm{C} 60$ molecule (C3) is able to raise the life span of mice about $300 \%$ while lacking mitochondrial manganese superoxide dismutase (MnSOD) [147]. On the other hand, cerium oxide NP (nanoceria) are established as neuroprotective agents lead to higher antioxidant properties and guard the cells from death due to oxidative stress shown in In-vitro experiments on isolated rat spinal cord neurons [148].

\subsection{Neuronal tissue regeneration}

The strategies for repair of damaged neuronal tissues involve the extracellular scaffolds which attached neuronal tissues and facilitate axonal growth. Neurotrophins (NT) and nanofibres (NF) have structural similarities with neuronal tissues, widely used as regenerative medicines. Jin et al. [149] recently synthesized a multi-walled carbon nano tube coated with electrospun poly (1-lactic acid-co-caprolactone) NF, indicated its potential for the prohibition of outgrowth of neurite in invitro experiments. On the other side, NT/NF both are utilized as scaffold and carrier for neurotrophin delivery, thus are involved in promotion, proliferation and differentiation of neurons. In-vivo experiments indicated that the incorporating potential of NF for nerve growth factor lead to effective regeneration and promotion of sciatic nerve [150]. One another approach leads to synthesis of electrically conducting NT/NF scaffolds for the enhancement of the regenerative processes with the future aspect for potentiating brain circuit activity. Electrically conducting nano-scaffolds broadly used in electrical stimulation of nerve stem cells due to their low obstruction and high charge transfer abilities [151]. Lee et al. in a combined approach, synthesized PLGA NF with electrically conducting polypyrrole covering which in in-vitro experiments act with nerve growth factor and lead neurite formation and outgrowth [152].

\section{Neurotoxicity of NM}

In spite of greater potential of NM in the field of biomedical, there is some possible toxic effect of NM also observed on CNS [49,137,153]. The available data indicated that various factors including shape, surface area, surface charge, size, chemical composition are responsible for toxicity of NM. At the latest, on the bases of surface chemistry (bare, $\backslash \mathrm{NH}_{2}$ or $\backslash \mathrm{COOH}$ functionalized) SPIONs has been investigated in-vitro neurotoxicity of on human neuroblastoma cell line at both cellular and molecular levels. It has been observed from MTT assay that the bare SPIONs have greater toxicity than those coated SPIONs, due to their increased tendency for absorption capability to vitamins, amino acids, and ions, leading to changes in $\mathrm{pH}$ and composition in cells and cell medium. DNA micro array experiments manifested that SPIONs-COOH provoke the up regulation of oxidative stress-inducible genes [154]. Various factors like size, shape (spheres, rods, and urchins)and surface coating (PEG or acetyl trimethyl ammonium bromide) of gold NP has been investigated via in-vitro and in-vivo experiments in term of their neurotoxicity.

Positively charged Au NPs exhibited toxicity on microglia and neurons during in-vitro experiments, independently of the shape. The intranasal administration of Au NPs during in-vivo experiments induced TLR-2 promoter activity and transient microglia activation in transgenic mice. The induction and the affinity depended on shape and surface of NP. Moreover, it has been observed that spheres, in particular $50 \mathrm{~nm}$ sized Au NPs indicated significantly great extent of cell interactions than rods [155].

For the investigation of neurotoxicity of commercially available NTs, PC12 cells are is commonly used in-vitro model for neuro toxicity studies. During an experiment, it has been observed that NTs decreased PC12 cell viability and mitochondrial membrane potential, dependent on time and dose while an increase in ROS production, the cell cycle arrest in the G2/M phase and the apoptotic rate depend only on the dose of NTs [156].

Zhang et al. found that the exposure of $\mathrm{TiO}_{2} \mathrm{NP}$ lead morphological changes of cortex neurons and disturb the levels of monoamine neurotransmitter in the sub-brain areas $[8,157]$. At the beginning some NP, indicated promising features in therapy and diagnosis but simultaneously their toxicity in the in-vivo experiments limited their clinical use. In the case of QD and NTs, repeated in-vivo toxicity limited their future use at the level of in vitro diagnosis. Thus, the benefit-risk balance should be carefully evaluated for nano technological approaches promised for brain drug delivery and diagnostics.

\section{Recent advancement in therapeutic strategies of neurodegenerative disorders}

\subsection{Cannabinoid therapeutics}

The classic hallmarks of the aged brain and neurodegenerative conditions involve abnormal protein accumulation, impaired lysosomal system, oxidative stress, excitotoxicity, and neuroinflammation [158]. The endocannabinoid system (ECS) has been emerged as a viable target for symptom alleviation or disease progression based on pharmacological modulation of endocannabinoid signaling, which involves both cannabinoid receptor-dependent effects and cannabinoid receptor independent effects [159]. The cannabinoid receptor-dependent effects are (i) activation of cannabinoid type-1 (CB1) receptors to normalize glutamate homeostasis or to activate autophagy; (ii) activation of cannabinoid type-2 (CB2) receptors and peroxisome proliferator-activated receptor $\gamma(\operatorname{PPAR} \gamma)$; (iii) modulation of G-protein receptor 55 (GPR55) to reduce local inflammatory events [160]. 


\subsection{Human fetal neural stem cell therapy}

Clinical trials using primary brain fetal tissue demonstrated the suitability of neural stem cell (NSC) therapy for neurodegenerative diseases. Based on supportive, preclinical proof-of-principle data, up to 21 somatic stem cell-based pilot trials have been developed for the treatment of ALS [161]. Immune-deficient models represent one of the elective experimental paradigms for the analysis of putative tumorigenicity of hNSC in vivo. Three of those studies have used hNSC lines: NCT01640067, NCT01348451 and NCT01730716. Interestingly, all the studies confirmed no acceleration in the course of the disease; on the contrary some of the patients showed a transient improvement of motor functions and ALS-FRS scale [162-164]. Although the data are encouraging, however this type of conclusions should be addressed more properly in larger phase II/III trial.

\subsection{D human brain cell models for neurodegenerative diseases}

Reason behind a high degree of failure in many recent clinical trials for disease-modifying therapeutics is the difficulty of translating findings from animal-based cell models to human patients. The majority of non-animal neurodegenerative disease research has been conducted in 2 dimensional (2D) models of rodent neonatal neurons and glia. The human stem cell technologies combined with microfluidic technologies have opened the door to development of patient-derived 3D brain cell models with the advantage in providing a micro-physiological system more closely reflecting the in vivo brain environment, and promote the interaction between different patient-derived brain cell-types. The new patient derived 3D brain cell systems will likely improve translational outcomes for disease therapeutics [165].

\section{Perspectives and conclusion}

Nowadays, scientists are investigating molecular, cellular and circuit functions of the CNS for the identification of causes and the pathways involved in neurodegeneration. The nanotechnological approaches are very progressive from the last few years in the direction of diagnosis and treatment of neurodegenerative disorders. However, more endeavors will be required in this arena for the conversion of preclinical experiments to substantial clinical exercises.

This is an arduous challenge for researchers, to develop feasible, compatible and acceptable theranostic NM for neurodegenerative disorders. Currently used magnetic ones indicated a successful candidature as theranostic due to their magnetic properties that may be utilized for MRI, tissue engineering and cell tracking, targeted drug and gene delivery systems. Recently, nanotechnology continuously working for development of novel tools which will emerge new insights in treatment and diagnosis of NDs.

\section{Disclosures}

There is no conflict of interest and disclosures associated with the manuscript.

\section{Acknowledgment}

Dr. Kesharwani acknowledges Science \& Engineering Research Board (SERB), New Delhi, India for providing Ramanujan fellowship.

\section{References}

[1] E. Neuwelt, N.J. Abbott, L. Abrey, W.A. Banks, B. Blakley, T. Davis, B. Engelhardt, P. Grammas, M. Nedergaard, J. Nutt, W. Pardridge, G.A. Rosenberg, Q. Smith, L.R. Drewes, Strategies to advance translational research into brain barriers, Lancet Neurol. 7 (2008) 84-96, https://doi.org/10.1016/S1474-4422(07) 70326-5.

[2] N. Dwivedi, J. Shah, V. Mishra, M.C.I. Mohd Amin, A.K. Iyer, R.K. Tekade,
P. Kesharwani, Dendrimer-mediated approaches for the treatment of brain tumor, J. Biomater. Sci. Polym. Ed. 27 (2016) 557-580, https://doi.org/10.1080/ 09205063.2015.1133155.

[3] V. Mishra, P. Kesharwani, Dendrimer technologies for brain tumor, Drug Discov. Today 21 (2016) 766-778, https://doi.org/10.1016/j.drudis.2016.02.006.

[4] S. Md, S.K. Bhattmisra, F. Zeeshan, N. Shahzad, M.A. Mujtaba, V. Srikanth Meka, A. Radhakrishnan, P. Kesharwani, S. Baboota, J. Ali, Nano-Carrier enabled drug delivery systems for nose to brain targeting for the treatment of neurodegenerative disorders, J. Drug Deliv. Sci. Technol. 43 (2018), https://doi.org/10.1016/j.jddst. 2017.09.022.

[5] R. Gabathuler, Approaches to transport therapeutic drugs across the blood-brain barrier to treat brain diseases, Neurobiol. Dis. 37 (2010) 48-57, https://doi.org/ 10.1016/j.nbd.2009.07.028.

[6] H.K. Patel, V. Gajbhiye, P. Kesharwani, N.K. Jain, Ligand anchored poly(propyleneimine) dendrimers for brain targeting: comparative in vitro and in vivo assessment, J. Colloid Interface Sci. 482 (2016) 142-150, https://doi.org/10.1016/j. jcis.2016.07.047.

[7] B. Gorain, H. Choudhury, M. Pandey, M.C.I. Mohd Amin, B. Singh, Dendrimers as effective carriers for the treatment of brain tumor, nanotechnology-based target, Drug Deliv. Syst. Brain Tumors (2018) 267-305, https://doi.org/10.1016/B978-0 12-812218-1.00010-5

[8] F. Re, M. Gregori, M. Masserini, L. An, Y. Zhang, et al., Nanotechnology for neurodegenerative disorders, Nanomedicine 8 (Suppl 1) (2012) S51-S58, https:// doi.org/10.1016/j.nano.2012.05.007.

[9] V. Mishra, A. Patil, S. Thakur, P. Kesharwani, Carbon dots: emerging theranostic nanoarchitectures, Drug Discov. Today (2018), https://doi.org/10.1016/j.drudis 2018.01.006.

[10] H. Wang, X. Chen, Applications for site-directed molecular imaging agents coupled with drug delivery potential, Expert Opin. Drug Deliv. 6 (2009) 745-768, https:// doi.org/10.1517/17425240902889751.

[11] B.L. Li, M.I. Setyawati, L. Chen, J. Xie, K. Ariga, C.-T. Lim, S. Garaj, D.T. Leong, Directing assembly and disassembly of $2 \mathrm{D} \mathrm{MoS}_{2}$ nanosheets with DNA for drug delivery, ACS Appl. Mater. Interfaces 9 (2017) 15286-15296, https://doi.org/10 1021/acsami.7b02529.

[12] B. Gorain, H. Choudhury, M. Pandey, P. Kesharwani, M.M. Abeer, R.K. Tekade, Z. Hussain, Carbon nanotube scaffolds as emerging nanoplatform for myocardial tissue regeneration: a review of recent developments and therapeutic implications, Biomed. Pharmacother. 104 (2018) 496-508, https://doi.org/10.1016/J.BIOPHA. 2018.05.066.

[13] M. Nakamura, Y. Tahara, S. Fukata, M. Zhang, M. Yang, S. Iijima, M. Yudasaka, Significance of optimization of phospholipid poly(ethylene glycol) quantity for coating carbon nanohorns to achieve low cytotoxicity, Bull. Chem. Soc. Jpn. 90 (2017) 662-666, https://doi.org/10.1246/bcsj.20170003.

[14] S. Kumar, R. Rani, N. Dilbaghi, K. Tankeshwar, K.-H. Kim, Carbon nanotubes: a novel material for multifaceted applications in human healthcare, Chem. Soc. Rev. 46 (2017) 158-196, https://doi.org/10.1039/C6CS00517A.

[15] Y.Y. Saptiama Indra, Yusuf Valentino Kaneti, Yumi Suzuki, Yoshitaka Suzuki, Kunihiko Tsuchiya, Sakae Takeji, Takai Kimiko, Fukumitsu Nobuyoshi, Alothman Zeid Abdullah, Md Hossain, A. Shahriar, Katsuhiko Ariga, Mesoporous alumina as an effective adsorbent for molybdenum (Mo) toward instant production of radioisotope for medical use metal-molecule hybrid structures view project MOFderived nanostructures and nanocomposites for energy storage and conversion devices view project, Bull. Chem. Soc. Jpn. 90 (2017) 1174-1179, https://doi.org/ $10.1246 /$ bcsj. 20170184

[16] K. Ariga, Nanoarchitectonics: a navigator from materials to life, Mater. Chem. Front. 1 (2017) 208-211, https://doi.org/10.1039/C6QM00240D.

[17] M. Komiyama, K. Yoshimoto, M. Sisido, K. Ariga, Chemistry can make strict and fuzzy controls for bio-systems: DNA nanoarchitectonics and cell-macromolecular nanoarchitectonics, Bull. Chem. Soc. Jpn. 90 (2017) 967-1004, https://doi.org/ 10.1246/bcsj.20170156.

[18] H.L. Wong, X.Y. Wu, R. Bendayan, Nanotechnological advances for the delivery of CNS therapeutics, Adv. Drug Deliv. Rev. 64 (2012) 686-700, https://doi.org/10. 1016/j.addr.2011.10.007.

[19] Y. Chen, L. Liu, Modern methods for delivery of drugs across the blood-brain barrier, Adv. Drug Deliv. Rev. 64 (2012) 640-665, https://doi.org/10.1016/j. addr.2011.11.010.

[20] C. Sun, Y. Ding, L. Zhou, D. Shi, L. Sun, T.J. Webster, Y. Shen, Noninvasive nanoparticle strategies for brain tumor targeting, Nanomed. Nanotechnol. Biol. Med. 13 (2017) 2605-2621, https://doi.org/10.1016/j.nano.2017.07.009.

[21] K.-T. Kim, H.S. Lee, J.-J. Lee, E.K. Park, B.-S. Lee, J.-Y. Lee, J.-S. Bae, Nanodelivery systems for overcoming limited transportation of therapeutic molecules through the blood-brain barrier, Future Med. Chem. (2018), https://doi.org/10.4155/fmc 2018-0208 fmc-2018-0208.

[22] Y. You, N. Wang, L. He, C. Shi, D. Zhang, Y. Liu, L. Luo, T. Chen, Designing dualfunctionalized carbon nanotubes with high blood-brain-barrier permeability for precise orthotopic glioma therapy, Dalton Trans. (2018), https://doi.org/10. 1039/c8dt03948h.

[23] N. Kumar, R. Kumar, Nanotechnology and nanomaterials in the treatment of life threatening diseases : nanomedicine, diagnostics and drug delivery, n.d.

[24] S. Bhaskar, F. Tian, T. Stoeger, W. Kreyling, J.M. de la Fuente, V. Grazú, P. Borm, G. Estrada, V. Ntziachristos, D. Razansky, Multifunctional Nanocarriers for diagnostics, drug delivery and targeted treatment across blood-brain barrier: perspectives on tracking and neuroimaging, Part. Fibre Toxicol. 7 (2010) 3, https:// doi.org/10.1186/1743-8977-7-3.

[25] G. De Rosa, G. Salzano, M. Caraglia, A. Abbruzzese, Nanotechnologies: a strategy to overcome blood-brain barrier, Curr. Drug Metabol. 13 (2012) 61-69 http:// 
www.ncbi.nlm.nih.gov/pubmed/22292810, Accessed date: 17 March 2017.

[26] P. Kesharwani, L. Xie, G. Mao, S. Padhye, A.K. Iyer, Hyaluronic Acid-Conjugated Polyamidoamine Dendrimers for Targeted Delivery of 3,4-difluorobenzylidene Curcumin to CD44 Overexpressing Pancreatic Cancer Cells 136 (2015), pp. 413-423, https://doi.org/10.1016/j.colsurfb.2015.09.043.

[27] P. Kesharwani, K. Jain, N.K. Jain, Dendrimer as Nanocarrier for Drug Delivery 39 (2014), pp. 268-307, https://doi.org/10.1016/j.progpolymsci.2013.07.005.

[28] S. Jain, P. Kesharwani, R.K. Tekade, N.K. Jain, One platform comparison of solubilization potential of dendrimer with some solubilizing agents, Drug Dev. Ind. Pharm. 41 (2015) 722-727, https://doi.org/10.3109/03639045.2014.900077.

[29] P. Kesharwani, V. Gajbhiye, R.K. Tekade, N.K. Jain, Evaluation of dendrimer safety and efficacy through cell line studies, Curr. Drug Targets 12 (2011) 1478-1497.

[30] J.E. Preston, N. Joan Abbott, D.J. Begley, Transcytosis of Macromolecules at the Blood-brain Barrier, (2014), pp. 147-163, https://doi.org/10.1016/bs.apha.2014 06.001.

[31] J.F. Poduslo, G.L. Curran, Increased permeability across the blood-nerve barrier of albumin glycated in vitro and in vivo from patients with diabetic polyneuropathy, Proc. Natl. Acad. Sci. U.S.A. 89 (1992) 2218-2222 http://www.ncbi.nlm.nih.gov/ pubmed/1549585 , Accessed date: 17 March 2017.

[32] C. Gavériaux-Ruff, B.L. Kieffer, Delta opioid receptor analgesia: recent contributions from pharmacology and molecular approaches, Behav. Pharmacol. 22 (2011) 405-414, https://doi.org/10.1097/FBP.0b013e32834a1f2c.

[33] M. Liu, K. Kono, J.M.J. Frechet, Water-soluble dendrimer-poly(ethylene glycol) starlike conjugates as potential drug carriers, J. Polym. Sci. Part A Polym. Chem. 37 (1999) 3492-3503, https://doi.org/10.1002/(SICI)1099-0518(19990901) 37:17<3492::AID-POLA7 > 3.0.CO;2-0.

[34] S. Thakur, P. Kesharwani, R.K. Tekade, N.K. Jain, Impact of pegylation on biopharmaceutical properties of dendrimers, Polymer (Guildf) 59 (2015) 67-92, https://doi.org/10.1016/j.polymer.2014.12.051.

[35] S. Thakur, R.K. Tekade, P. Kesharwani, N.K. Jain, The effect of polyethylene glycol spacer chain length on the tumor-targeting potential of folate-modified PPI dendrimers, J. Nanoparticle Res. 15 (2013) 1625, https://doi.org/10.1007/s11051013-1625-2.

[36] D. Luong, P. Kesharwani, R. Deshmukh, M.C.I. Mohd Amin, U. Gupta, K. Greish, A.K. Iyer, PEGylated PAMAM dendrimers: enhancing efficacy and mitigating toxicity for effective anticancer drug and gene delivery, Acta Biomater. (2016), https://doi.org/10.1016/j.actbio.2016.07.015.

[37] A. Jain, P. Kesharwani, N.K. Garg, A. Jain, S.A. Jain, A.K. Jain, P. Nirbhavane, R. Ghanghoria, R.K. Tyagi, O.P. Katare, Galactose engineered solid lipid nanoparticles for targeted delivery of doxorubicin, Colloids Surfaces B Biointerfaces (2015), https://doi.org/10.1016/j.colsurfb.2015.06.027.

[38] D. Luong, P. Kesharwani, R. Deshmukh, M.C.I. Mohd Amin, U. Gupta, K. Greish, A.K. Iyer, PEGylated PAMAM dendrimers: enhancing efficacy and mitigating toxicity for effective anticancer drug and gene delivery, Acta Biomater. (2016), https://doi.org/10.1016/j.actbio.2016.07.015.

[39] R.D. Egleton, T.P. Davis, Development of neuropeptide drugs that cross the bloodbrain barrier, NeuroRx 2 (2005) 44-53, https://doi.org/10.1602/neurorx.2.1.44.

[40] J.A. MacKay, D.F. Deen, F.C. Szoka, Distribution in brain of liposomes after convection enhanced delivery; modulation by particle charge, particle diameter, and presence of steric coating, Brain Res. 1035 (2005) 139-153, https://doi.org/10. 1016/j.brainres.2004.12.007.

[41] T.-E. Park, B. Singh, H. Li, J.-Y. Lee, S.-K. Kang, Y.-J. Choi, C.-S. Cho, Enhanced BBB permeability of osmotically active poly(mannitol-co-PEI) modified with rabies virus glycoprotein via selective stimulation of caveolar endocytosis for RNAi therapeutics in Alzheimer's disease, Biomaterials 38 (2015) 61-71, https://doi. org/10.1016/j.biomaterials.2014.10.068.

[42] B. Perlstein, Z. Ram, D. Daniels, A. Ocherashvilli, Y. Roth, S. Margel, Y. Mardor, Convection-enhanced delivery of maghemite nanoparticles: increased efficacy and MRI monitoring, Neuro Oncol. 10 (2008) 153-161, https://doi.org/10.1215/ 15228517-2008-002.

[43] M.Y. Chen, A. Hoffer, P.F. Morrison, J.F. Hamilton, J. Hughes, K.S. Schlageter, J. Lee, B.R. Kelly, E.H. Oldfield, Surface properties, more than size, limiting convective distribution of virus-sized particles and viruses in the central nervous system, J. Neurosurg. 103 (2005) 311-319, https://doi.org/10.3171/jns.2005. 103.2 .0311$.

[44] Y. Mardor, O. Rahav, Y. Zauberman, Z. Lidar, A. Ocherashvilli, D. Daniels, Y. Roth, S.E. Maier, A. Orenstein, Z. Ram, Convection-enhanced drug delivery: increased efficacy and magnetic resonance image monitoring, Cancer Res. 65 (2005) 6858-6863, https://doi.org/10.1158/0008-5472.CAN-05-0161.

[45] D. Triguero, J.B. Buciak, J. Yang, W.M. Pardridge, Blood-brain barrier transport of cationized immunoglobulin G: enhanced delivery compared to native protein,

Proc. Natl. Acad. Sci. U.S.A. 86 (1989) 4761-4765 http://www.ncbi.nlm.nih.gov/ pubmed/2734318, Accessed date: 17 March 2017.

[46] R. Prades, S. Guerrero, E. Araya, C. Molina, E. Salas, E. Zurita, J. Selva, G. Egea, C. López-Iglesias, M. Teixidó, M.J. Kogan, E. Giralt, Delivery of gold nanoparticles to the brain by conjugation with a peptide that recognizes the transferrin receptor, Biomaterials 33 (2012) 7194-7205, https://doi.org/10.1016/j.biomaterials.2012. 06.063.

[47] I. Kratzer, K. Wernig, U. Panzenboeck, E. Bernhart, H. Reicher, R. Wronski, M. Windisch, A. Hammer, E. Malle, A. Zimmer, W. Sattler, Apolipoprotein A-I coating of protamine-oligonucleotide nanoparticles increases particle uptake and transcytosis in an in vitro model of the blood-brain barrier, J. Contr. Release 117 (2007) 301-311, https://doi.org/10.1016/j.jconrel.2006.11.020.

[48] A. Zensi, D. Begley, C. Pontikis, C. Legros, L. Mihoreanu, C. Büchel, J. Kreuter, Human serum albumin nanoparticles modified with apolipoprotein A-I cross the blood-brain barrier and enter the rodent brain, J. Drug Target. 18 (2010) 842-848, https://doi.org/10.3109/1061186X.2010.513712.

[49] K. Ulbrich, T. Hekmatara, E. Herbert, J. Kreuter, Transferrin- and transferrin-receptor-antibody-modified nanoparticles enable drug delivery across the bloodbrain barrier (BBB), Eur. J. Pharm. Biopharm. 71 (2009) 251-256, https://doi. org/10.1016/j.ejpb.2008.08.021.

[50] R.J. Boado, A new generation of neurobiological drugs engineered to overcome the challenges of brain drug delivery, Drug News Perspect. 21 (2008) 489, https:// doi.org/10.1358/dnp.2008.21.9.1290820.

[51] Louis S. Goodman, L.L. Brunton, B. Chabner, B.C. Knollmann, Goodman \& Gilman's Pharmacological Basis of Therapeutics, McGraw-Hill, 2011.

[52] L.M. Ittner, J. Götz, Amyloid- $\beta$ and tau-a toxic pas de deux in Alzheimer's disease, Nat. Rev. Neurosci. 12 (2011) 65-72, https://doi.org/10.1038/nrn2967.

[53] D. Karlsson, A. Fallarero, G. Brunhofer, P. Guzik, M. Prinz, U. Holzgrabe, T. Erker, P. Vuorela, Identification and characterization of diarylimidazoles as hybrid inhibitors of butyrylcholinesterase and amyloid beta fibril formation, Eur. J. Pharm. Sci. 45 (2012) 169-183, https://doi.org/10.1016/j.ejps.2011.11.004.

[54] J. Xiang, C. Yu, F. Yang, L. Yang, H. Ding, Conformation-activity studies on the interaction of berberine with acetylcholinesterase: physical chemistry approach, Prog. Nat. Sci. 19 (2009) 1721-1725, https://doi.org/10.1016/j.pnsc.2009.07. 010 .

[55] A.C. Tricco, C. Soobiah, S. Berliner, J.M. Ho, C.H. Ng, H.M. Ashoor, M.H. Chen, B. Hemmelgarn, S.E. Straus, Efficacy and safety of cognitive enhancers for patients with mild cognitive impairment: a systematic review and meta-analysis, CMAJ 185 (2013) 1393-1401, https://doi.org/10.1503/cmaj.130451.

[56] I. Molino, L. Colucci, A.M. Fasanaro, E. Traini, F. Amenta, Efficacy of memantine, donepezil, or their association in moderate-severe Alzheimer's disease: a review of clinical trials, Sci. World J. 2013 (2013) 1-8, https://doi.org/10.1155/2013/ 925702.

[57] A.C. Tricco, C. Soobiah, S. Berliner, J.M. Ho, C.H. Ng, H.M. Ashoor, M.H. Chen, B. Hemmelgarn, S.E. Straus, Efficacy and safety of cognitive enhancers for patients with mild cognitive impairment: a systematic review and meta-analysis, Can. Med. Assoc. J. 185 (2013) 1393-1401, https://doi.org/10.1503/cmaj.130451.

[58] D. Brambilla, B. Le Droumaguet, J. Nicolas, S.H. Hashemi, L.-P. Wu, S.M. Moghimi, P. Couvreur, K. Andrieux, Nanotechnologies for Alzheimer's disease: diagnosis, therapy, and safety issues, Nanomed. Nanotechnol. Biol. Med. 7 (2011) 521-540, https://doi.org/10.1016/j.nano.2011.03.008.

[59] Y. Matsuoka, M. Saito, J. LaFrancois, M. Saito, K. Gaynor, V. Olm, L. Wang, E. Casey, Y. Lu, C. Shiratori, C. Lemere, K. Duff, Novel therapeutic approach for the treatment of Alzheimer's disease by peripheral administration of agents with an affinity to beta-amyloid, J. Neurosci. 23 (2003) 29-33 http://www.ncbi.nlm. nih.gov/pubmed/12514198, Accessed date: 17 March 2017.

[60] M. Gobbi, F. Re, M. Canovi, M. Beeg, M. Gregori, S. Sesana, S. Sonnino, D. Brogioli, C. Musicanti, P. Gasco, M. Salmona, M.E. Masserini, Lipid-based nanoparticles with high binding affinity for amyloid- $\beta 1-42$ peptide, Biomaterials 31 (2010) 6519-6529, https://doi.org/10.1016/j.biomaterials.2010.04.044.

[61] E. Bereczki, F. Re, M.E. Masserini, B. Winblad, J.J. Pei, Liposomes functionalized with acidic lipids rescue $A \beta$-induced toxicity in murine neuroblastoma cells, Nanomedicine 7 (2011) 560-571, https://doi.org/10.1016/j.nano.2011.05.009.

[62] M. Canovi, E. Markoutsa, A.N. Lazar, G. Pampalakis, C. Clemente, F. Re, S. Sesana, M. Masserini, M. Salmona, C. Duyckaerts, O. Flores, M. Gobbi, S.G. Antimisiaris, The binding affinity of anti-A $\beta 1-42$ MAb-decorated nanoliposomes to A $\beta 1-42$ peptides in vitro and to amyloid deposits in post-mortem tissue, Biomaterials 32 (2011) 5489-5497, https://doi.org/10.1016/j.biomaterials.2011.04.020.

[63] S. Mourtas, M. Canovi, C. Zona, D. Aurilia, A. Niarakis, B. La Ferla, M. Salmona, F. Nicotra, M. Gobbi, S.G. Antimisiaris, Curcumin-decorated nanoliposomes with very high affinity for amyloid- $\beta 1-42$ peptide, Biomaterials 32 (2011) 1635-1645, https://doi.org/10.1016/j.biomaterials.2010.10.027.

[64] M. Taylor, S. Moore, S. Mourtas, A. Niarakis, F. Re, C. Zona, B. La Ferla, F. Nicotra M. Masserini, S.G. Antimisiaris, M. Gregori, D. Allsop, Effect of curcumin-associated and lipid ligand-functionalized nanoliposomes on aggregation of the Alzheimer's A $\beta$ peptide, Nanomedicine 7 (2011) 541-550, https://doi.org/10. 1016/j.nano.2011.06.015.

[65] G. Orteca, F. Tavanti, Z. Bednarikova, Z. Gazova, G. Rigillo, C. Imbriano, V. Basile, M. Asti, L. Rigamonti, M. Saladini, E. Ferrari, M.C. Menziani, Curcumin derivatives and A $\beta$-fibrillar aggregates: an interactions' study for diagnostic/therapeutic purposes in neurodegenerative diseases, Bioorg. Med. Chem. 26 (2018) 4288-4300, https://doi.org/10.1016/j.bmc.2018.07.027.

[66] A. Janaszewska, B. Ziemba, K. Ciepluch, D. Appelhans, B. Voit, B. Klajnert, M. Bryszewska, B. Voit, M.F. Ottaviani, M. Bryszewska, B. Voit, The biodistribution of maltotriose modified poly(propylene imine) (PPI) dendrimers conjugated with fluorescein-proofs of crossing blood-brain-barrier, New J. Chem. 36 (2012) 350-353, https://doi.org/10.1039/C1NJ20444K.

[67] B. Klajnert, M. Cortijo-Arellano, J. Cladera, M. Bryszewska, Influence of dendrimer's structure on its activity against amyloid fibril formation, Biochem. Biophys. Res. Commun. 345 (2006) 21-28, https://doi.org/10.1016/j.bbrc.2006. 04.041

[68] T. Wasiak, M. Ionov, K. Nieznanski, H. Nieznanska, O. Klementieva, M. Granell, J. Cladera, J.-P. Majoral, A.M. Caminade, B. Klajnert, Phosphorus dendrimers affect Alzheimer's (A $\beta_{1-28}$ ) peptide and MAP-tau protein aggregation, Mol. Pharm 9 (2012) 458-469, https://doi.org/10.1021/mp2005627.

[69] K. Ciepluch, M. Weber, N. Katir, A.-M. Caminade, A. El Kadib, B. Klajnert, J.P. Majoral, M. Bryszewska, Effect of viologen-phosphorus dendrimers on acetylcholinesterase and butyrylcholinesterase activities, Int. J. Biol. Macromol. 54 (2013) 119-124, https://doi.org/10.1016/j.ijbiomac.2012.12.002.

[70] B. Klajnert, T. Wasiak, M. Ionov, M. Fernandez-Villamarin, A. Sousa-Herves, 
J. Correa, R. Riguera, E. Fernandez-Megia, Dendrimers reduce toxicity of A $\beta$ 1-28 peptide during aggregation and accelerate fibril formation, Nanomedicine 8 (2012) 1372-1378, https://doi.org/10.1016/j.nano.2012.03.005.

[71] R.M. Burke, T.A. Norman, T.F. Haydar, B.E. Slack, S.E. Leeman, J.K. Blusztajn, T.J. Mellott, BMP9 ameliorates amyloidosis and the cholinergic defect in a mouse model of Alzheimer's disease, Proc. Natl. Acad. Sci. 110 (2013) 19567-19572, https://doi.org/10.1073/pnas.1319297110.

[72] Q. Lv, W. Lan, W. Sun, R. Ye, X. Fan, M. Ma, Q. Yin, Y. Jiang, G. Xu, J. Dai, R. Guo, $\mathrm{X}$. Liu, Intranasal nerve growth factor attenuates tau phosphorylation in brain after traumatic brain injury in rats, J. Neurol. Sci. 345 (2014) 48-55, https://doi. org/10.1016/j.jns.2014.06.037.

[73] J. Zhang, B.M. Moats-Staats, P. Ye, A.J. D'Ercole, Expression of insulin-like growth factor system genes during the early postnatal neurogenesis in the mouse hippocampus, J. Neurosci. Res. 85 (2007) 1618-1627, https://doi.org/10.1002/jnr. 21289.

[74] J. O'Kusky, P. Ye, Neurodevelopmental effects of insulin-like growth factor signaling, Front. Neuroendocrinol. 33 (2012) 230-251, https://doi.org/10.1016/j. yfrne.2012.06.002.

[75] J. Freiherr, M. Hallschmid, W.H. Frey, Y.F. Brünner, C.D. Chapman, C. Hölscher, S. Craft, F.G. De Felice, C. Benedict, Intranasal insulin as a treatment for Alzheimer's disease: a review of basic research and clinical evidence, CNS Drugs 27 (2013) 505-514, https://doi.org/10.1007/s40263-013-0076-8.

[76] M. Pascual-Lucas, S. Viana da Silva, M. Di Scala, C. Garcia-Barroso, G. GonzalezAseguinolaza, C. Mulle, C.M. Alberini, M. Cuadrado-Tejedor, A. Garcia-Osta, Insulin-like growth factor 2 reverses memory and synaptic deficits in APP transgenic mice, EMBO Mol. Med. 6 (2014) 1246-1262, https://doi.org/10.15252/ emmm.201404228.

[77] I. Lopez-Coviella, T.J. Mellott, A.C. Schnitzler, J.K. Blusztajn, BMP9 protects septal neurons from axotomy-evoked loss of cholinergic phenotype, PLoS One 6 (2011) e21166, , https://doi.org/10.1371/journal.pone.0021166.

[78] I. López-Coviella, B. Berse, R.S. Thies, J.K. Blusztajn, Upregulation of acetylcholine synthesis by bone morphogenetic protein 9 in a murine septal cell line., J. Physiol. Paris 96 (n.d.) 53-9. http://www.ncbi.nlm.nih.gov/pubmed/11755783 (Accessed March 17, 2017).

[79] J. Ye, H. Lin, J. Mu, X. Cui, H. Ying, M. Lin, L. Wu, J. Weng, X. Lin, Effect of basic fibroblast growth factor on hippocampal cholinergic neurons in a rodent model of ischaemic encephalopathy, Basic Clin. Pharmacol. Toxicol. 107 (2010) 931-939, https://doi.org/10.1111/j.1742-7843.2010.00603.x.

[80] T. Kiyota, K.L. Ingraham, M.T. Jacobsen, H. Xiong, T. Ikezu, FGF2 gene transfer restores hippocampal functions in mouse models of Alzheimer's disease and has therapeutic implications for neurocognitive disorders, Proc. Natl. Acad. Sci. 108 (2011) E1339-E1348, https://doi.org/10.1073/pnas.1102349108.

[81] T. Noshita, N. Murayama, T. Oka, R. Ogino, S. Nakamura, T. Inoue, Effect of bFGF on neuronal damage induced by sequential treatment of amyloid $\beta$ and excitatory amino acid in vitro and in vivo, Eur. J. Pharmacol. 695 (2012) 76-82, https://doi. org/10.1016/j.ejphar.2012.09.020.

[82] S. Revilla, S. Ursulet, M.J. Álvarez-López, M. Castro-Freire, U. Perpiñá, Y. GarcíaMesa, A. Bortolozzi, L. Giménez-Llort, P. Kaliman, R. Cristòfol, C. Sarkis, C. Sanfeliu, Lenti-gdnf gene therapy protects against Alzheimer's disease-like neuropathology in 3xTg-AD mice and MC65 cells, CNS Neurosci. Ther. 20 (2014) 961-972, https://doi.org/10.1111/cns.12312.

[83] S.J. Allen, J.J. Watson, D.K. Shoemark, N.U. Barua, N.K. Patel, GDNF, NGF and BDNF as therapeutic options for neurodegeneration, Pharmacol. Ther. 138 (2013) 155-175, https://doi.org/10.1016/j.pharmthera.2013.01.004.

[84] C. Matrone, M.T. Ciotti, D. Mercanti, R. Marolda, P. Calissano, NGF and BDNF signaling control amyloidogenic route and A production in hippocampal neurons, Proc. Natl. Acad. Sci. 105 (2008) 13139-13144, https://doi.org/10.1073/pnas. 0806133105

[85] C. Matrone, A. Di Luzio, G. Meli, S. D'Aguanno, C. Severini, M.T. Ciotti, A. Cattaneo, P. Calissano, Activation of the amyloidogenic route by NGF deprivation induces apoptotic death in PC12 cells, J. Alzheimers. Dis. 13 (2008) 81-96 http://www.ncbi.nlm.nih.gov/pubmed/18334760 , Accessed date: 17 March 2017.

[86] N. Kitiyanant, Y. Kitiyanant, C.N. Svendsen, W. Thangnipon, BDNF-, IGF-1- and GDNF-secreting human neural progenitor cells rescue amyloid $\beta$-induced toxicity in cultured rat septal neurons, Neurochem. Res. 37 (2012) 143-152, https://doi. org/10.1007/s11064-011-0592-1.

[87] S. Arancibia, M. Silhol, F. Moulière, J. Meffre, I. Höllinger, T. Maurice, L. TapiaArancibia, Protective effect of BDNF against beta-amyloid induced neurotoxicity in vitro and in vivo in rats, Neurobiol. Dis. 31 (2008) 316-326, https://doi.org/10 1016/j.nbd.2008.05.012.

[88] M.-A. Lauzon, A. Daviau, B. Marcos, N. Faucheux, Nanoparticle-mediated growth factor delivery systems: a new way to treat Alzheimer's disease, J. Contr. Release 206 (2015) 187-205, https://doi.org/10.1016/j.jconrel.2015.03.024.

[89] Z. Yang, Y. Zhang, Y. Yang, L. Sun, D. Han, H. Li, C. Wang, Pharmacological and toxicological target organelles and safe use of single-walled carbon nanotubes as drug carriers in treating Alzheimer disease, Nanomed. Nanotechnol. Biol. Med. 6 (2010) 427-441, https://doi.org/10.1016/j.nano.2009.11.007.

[90] J.K. Sahni, S. Doggui, J. Ali, S. Baboota, L. Dao, C. Ramassamy, Neurotherapeutic applications of nanoparticles in Alzheimer's disease, J. Contr. Release 152 (2011) 208-231, https://doi.org/10.1016/j.jconrel.2010.11.033.

[91] G.A. Krafft, W.L. Klein, ADDLs and the signaling web that leads to Alzheimer's disease, Neuropharmacology 59 (2010) 230-242, https://doi.org/10.1016/j. neuropharm.2010.07.012

[92] C.R. Jack, D.S. Knopman, W.J. Jagust, R.C. Petersen, M.W. Weiner, P.S. Aisen, L.M. Shaw, P. Vemuri, H.J. Wiste, S.D. Weigand, T.G. Lesnick, V.S. Pankratz,
M.C. Donohue, J.Q. Trojanowski, Tracking pathophysiological processes in Alzheimer's disease: an updated hypothetical model of dynamic biomarkers, Lancet Neurol. 12 (2013) 207-216, https://doi.org/10.1016/S1474-4422(12) 70291-0.

[93] R. Ni, P.-G. Gillberg, A. Bergfors, A. Marutle, A. Nordberg, Amyloid tracers detect multiple binding sites in Alzheimer's disease brain tissue, Brain 136 (2013) 2217-2227, https://doi.org/10.1093/brain/awt142.

[94] A. Nordberg, J.O. Rinne, A. Kadir, B. Långström, The use of PET in Alzheimer disease, Nat. Rev. Neurol. 6 (2010) 78-87, https://doi.org/10.1038/nrneurol. 2009.217.

[95] S. Laurent, D. Forge, M. Port, A. Roch, C. Robic, L. Vander Elst, R.N. Muller, Magnetic iron oxide nanoparticles: synthesis, stabilization, vectorization, physicochemical characterizations, and biological applications, Chem. Rev. 108 (2008) 2064-2110, https://doi.org/10.1021/cr068445e.

[96] S. Wagner, J. Schnorr, H. Pilgrimm, B. Hamm, M. Taupitz, Monomer-coated very small superparamagnetic iron oxide particles as contrast medium for magnetic resonance imaging: preclinical in vivo characterization, Invest. Radiol. 37 (2002) 167-177 http://www.ncbi.nlm.nih.gov/pubmed/11923639 , Accessed date: 17 March 2017.

[97] A. Saleh, M. Schroeter, A. Ringelstein, H.-P. Hartung, M. Siebler, U. Mödder, S. Jander, Iron oxide particle-enhanced MRI suggests variability of brain inflammation at early stages after ischemic stroke, Stroke 38 (2007) 2733-2737, https://doi.org/10.1161/STROKEAHA.107.481788.

[98] D.T. Winkler, L. Bondolfi, M.C. Herzig, L. Jann, M.E. Calhoun, K.H. Wiederhold, M. Tolnay, M. Staufenbiel, M. Jucker, P. Paganetti, C. Waridel, M. Calhoun, M. Jucker, A. Probst, M. Staufenbiel, B. Sommer, Spontaneous hemorrhagic stroke in a mouse model of cerebral amyloid angiopathy, J. Neurosci. 21 (2001) 1619-1627, https://doi.org/10.1016/J.NEUROSCIENCE.2006.10.020.

[99] S. Arancibia, M. Silhol, F. Moulière, J. Meffre, I. Höllinger, T. Maurice, L. TapiaArancibia, Protective effect of BDNF against beta-amyloid induced neurotoxicity in vitro and in vivo in rats, Neurobiol. Dis. 31 (2008) 316-326, https://doi.org/10. 1016/j.nbd.2008.05.012

[100] Y.Z. Wadghiri, J. Li, J. Wang, D.M. Hoang, Y. Sun, H. Xu, W. Tsui, Y. Li, A. Boutajangout, A. Wang, M. de Leon, T. Wisniewski, Detection of amyloid plaques targeted by bifunctional USPIO in alzheimer's disease transgenic mice using magnetic resonance microimaging, PLoS One 8 (2013) e57097, , https://doi.org/ 10.1371/journal.pone.0057097.

[101] D.-Y. Kang, J.-H. Lee, B.-K. Oh, J.-W. Choi, Ultra-sensitive immunosensor for $\beta$ amyloid (1-42) using scanning tunneling microscopy-based electrical detection, Biosens. Bioelectron. 24 (2009) 1431-1436, https://doi.org/10.1016/j.bios.2008. 08.018.

[102] C.-C. Yang, S.-Y. Yang, J.-J. Chieh, H.-E. Horng, C.-Y. Hong, H.-C. Yang, K.H. Chen, B.Y. Shih, T.-F. Chen, M.-J. Chiu, Biofunctionalized magnetic nanoparticles for specifically detecting biomarkers of Alzheimer's disease in vitro, ACS Chem. Neurosci. 2 (2011) 500-505, https://doi.org/10.1021/cn200028j.

[103] A. Neely, C. Perry, B. Varisli, A.K. Singh, T. Arbneshi, D. Senapati, J.R. Kalluri, P.C. Ray, Ultrasensitive and highly selective detection of Alzheimer's disease biomarker using two-photon Rayleigh scattering properties of gold nanoparticle, ACS Nano 3 (2009) 2834-2840, https://doi.org/10.1021/nn900813b.

[104] M. Chikae, T. Fukuda, K. Kerman, K. Idegami, Y. Miura, E. Tamiya, Amyloid- $\beta$ detection with saccharide immobilized gold nanoparticle on carbon electrode, Bioelectrochemistry 74 (2008) 118-123, https://doi.org/10.1016/j.bioelechem. 2008.06.005.

[105] D.G. Georganopoulou, L. Chang, J.-M. Nam, C.S. Thaxton, E.J. Mufson, W.L. Klein, C.A. Mirkin, Nanoparticle-based detection in cerebral spinal fluid of a soluble pathogenic biomarker for Alzheimer's disease, Proc. Natl. Acad. Sci. U.S.A. 102 (2005) 2273-2276, https://doi.org/10.1073/pnas.0409336102.

[106] M. Kosicek, S. Kirsch, R. Bene, Z. Trkanjec, M. Titlic, L. Bindila, J. Peter-Katalinic, S. Hecimovic, Nano-HPLC-MS analysis of phospholipids in cerebrospinal fluid of Alzheimer's disease patients-a pilot study, Anal. Bioanal. Chem. 398 (2010) 2929-2937, https://doi.org/10.1007/s00216-010-4273-8.

[107] L. Feng, S. Li, B. Xiao, S. Chen, R. Liu, Y. Zhang, Fluorescence imaging of APP in Alzheimer's disease with quantum dot or Cy3: a comparative study, Zhong Nan Da Xue Xue Bao. Yi Xue Ban. 35 (2010) 903-909, https://doi.org/10.3969/j.issn. 1672-7347.2010.09.001.

[108] Y.Z. Wadghiri, J. Li, J. Wang, D.M. Hoang, Y. Sun, H. Xu, W. Tsui, Y. Li, A. Boutajangout, A. Wang, M. de Leon, T. Wisniewski, Detection of amyloid plaques targeted by bifunctional USPIO in Alzheimer's disease transgenic mice using magnetic resonance microimaging, PLoS One 8 (2013) e57097, , https://doi.org/ 10.1371/journal.pone.0057097.

[109] C.A. Roney, V. Arora, P. V Kulkarni, P.P. Antich, F.J. Bonte, Nanoparticulate radiolabelled quinolines detect amyloid plaques in mouse models of Alzheimer's disease, Int. J. Alzheimer's Dis. (2009), https://doi.org/10.4061/2009/481031 2010

[110] L.M.L. de Lau, M.M.B. Breteler, E. Louis, R. Mayeux, P. Williamson, et al., Epidemiology of Parkinson's disease, Lancet Neurol. 5 (2006) 525-535, https:// doi.org/10.1016/S1474-4422(06)70471-9.

[111] N.B. Cole, D.D. Murphy, The cell biology of $\alpha$ synuclein, NeuroMolecular Med. 1 (2002) 95-110, https://doi.org/10.1385/NMM:1:2:95.

[112] W.G. Meissner, M. Frasier, T. Gasser, C.G. Goetz, A. Lozano, P. Piccini, J.A. Obeso, O. Rascol, A. Schapira, V. Voon, D.M. Weiner, F. Tison, E. Bezard, Priorities in Parkinson's disease research, Nat. Rev. Drug Discov. 10 (2011) 377-393, https:// doi.org/10.1038/nrd3430.

[113] M.N. Tiwari, S. Agarwal, P. Bhatnagar, N.K. Singhal, S.K. Tiwari, P. Kumar, L.K.S. Chauhan, D.K. Patel, R.K. Chaturvedi, M.P. Singh, K.C. Gupta, Nicotineencapsulated poly(lactic-co-glycolic) acid nanoparticles improve neuroprotective 
efficacy against MPTP-induced parkinsonism, Free Radic. Biol. Med. 65 (2013) 704-718, https://doi.org/10.1016/j.freeradbiomed.2013.07.042.

[114] G. Leyva-Gómez, H. Cortés, J.J. Magaña, N. Leyva-García, D. Quintanar-Guerrero, B. Florán, Nanoparticle technology for treatment of Parkinson's disease: the role of surface phenomena in reaching the brain, Drug Discov. Today 20 (2015) 824-837, https://doi.org/10.1016/j.drudis.2015.02.009.

[115] A. Trapani, E. De Giglio, D. Cafagna, N. Denora, G. Agrimi, T. Cassano, S. Gaetani, V. Cuomo, G. Trapani, Characterization and evaluation of chitosan nanoparticles for dopamine brain delivery, Int. J. Pharm. 419 (2011) 296-307, https://doi.org/ 10.1016/j.ijpharm.2011.07.036.

[116] R. Huang, W. Ke, Y. Liu, D. Wu, L. Feng, C. Jiang, Y. Pei, Gene therapy using lactoferrin-modified nanoparticles in a rotenone-induced chronic Parkinson model, J. Neurol. Sci. 290 (2010) 123-130, https://doi.org/10.1016/j.jns.2009. 09.032 .

[117] Z. Wen, Z. Yan, K. Hu, Z. Pang, X. Cheng, L. Guo, Q. Zhang, X. Jiang, L. Fang, R. Lai, Odorranalectin-conjugated nanoparticles: preparation, brain delivery and pharmacodynamic study on Parkinson's disease following intranasal administration, J. Contr. Release 151 (2011) 131-138, https://doi.org/10.1016/j.jconrel. 2011.02.022.

[118] K. Hu, Y. Shi, W. Jiang, J. Han, S. Huang, X. Jiang, Lactoferrin conjugated PEGPLGA nanoparticles for brain delivery: preparation, characterization and efficacy in Parkinson's disease, Int. J. Pharm. 415 (2011) 273-283, https://doi.org/10. 1016/j.ijpharm.2011.05.062.

[119] K. Milowska, M. Malachowska, T. Gabryelak, PAMAM G4 dendrimers affect the aggregation of $\alpha$-synuclein, Int. J. Biol. Macromol. 48 (2011) 742-746, https:// doi.org/10.1016/j.ijbiomac.2011.02.021.

[120] K. Milowska, T. Gabryelak, M. Bryszewska, A.-M. Caminade, J.-P. Majoral, Phosphorus-containing dendrimers against $\alpha$-synuclein fibril formation, Int. J. Biol. Macromol. 50 (2012) 1138-1143, https://doi.org/10.1016/j.ijbiomac.2012. 02.003.

[121] K. Milowska, J. Grochowina, N. Katir, A. El Kadib, J.-P. Majoral, M. Bryszewska, T. Gabryelak, Viologen-phosphorus dendrimers inhibit $\alpha$-synuclein fibrillation, Mol. Pharm. 10 (2013) 1131-1137, https://doi.org/10.1021/mp300636h.

[122] K. Ciepluch, M. Weber, N. Katir, A.-M. Caminade, A. El Kadib, B. Klajnert, J.P. Majoral, M. Bryszewska, Effect of viologen-phosphorus dendrimers on acetylcholinesterase and butyrylcholinesterase activities, Int. J. Biol. Macromol. 54 (2013) 119-124, https://doi.org/10.1016/j.ijbiomac.2012.12.002.

[123] K. Milowska, A. Szwed, M. Mutrynowska, R. Gomez-Ramirez, F.J. de la Mata, T. Gabryelak, M. Bryszewska, Carbosilane dendrimers inhibit $\alpha$-synuclein fibrillation and prevent cells from rotenone-induced damage, Int. J. Pharm. 484 (2015) 268-275, https://doi.org/10.1016/j.ijpharm.2015.02.066.

[124] M. Qu, Q. Lin, L. Huang, Y. Fu, L. Wang, S. He, Y. Fu, S. Yang, Z. Zhang, L. Zhang, $\mathrm{X}$. Sun, Dopamine-loaded blood exosomes targeted to brain for better treatment of Parkinson's disease, J. Contr. Release 287 (2018) 156-166, https://doi.org/10. 1016/j.jconrel.2018.08.035.

[125] E. Bezard, C.E. Gross, J.M. Brotchie, Presymptomatic compensation in Parkinson's disease is not dopamine-mediated, Trends Neurosci. 26 (2003) 215-221, https:// doi.org/10.1016/S0166-2236(03)00038-9.

[126] J. Brotchie, C. Fitzer-Attas, Mechanisms compensating for dopamine loss in early Parkinson disease, Neurology 72 (2009) S32-S38, https://doi.org/10.1212/WNL. 0b013e318198e0e9.

[127] K.G. Lloyd, CNS compensation to dopamine neuron loss in Parkinson's disease, Adv. Exp. Med. Biol. 90 (1977) 255-266 http://www.ncbi.nlm.nih.gov/pubmed/ 930746 , Accessed date: 17 March 2017.

[128] J.K. Qiang, Y.C. Wong, A. Siderowf, H.I. Hurtig, S.X. Xie, V.M.-Y. Lee, J.Q. Trojanowski, D. Yearout, J.B. Leverenz, T.J. Montine, M. Stern, S. Mendick, D. Jennings, C. Zabetian, K. Marek, A.S. Chen-Plotkin, Plasma apolipoprotein A1 as a biomarker for Parkinson disease, Ann. Neurol. 74 (2013) 119-127, https:// doi.org/10.1002/ana.23872.

[129] E.-S. Wang, H.-B. Yao, Y.-H. Chen, G. Wang, W.-W. Gao, Y.-R. Sun, J.-G. Guo, J.W. Hu, C.-C. Jiang, J. Hu, Proteomic analysis of the cerebrospinal fluid of Parkinson's disease patients pre- and post-deep brain stimulation, Cell. Physiol. Biochem. 31 (2013) 625-637, https://doi.org/10.1159/000350082.

[130] P. Crawford, E.E. Zimmerman, Differentiation and diagnosis of tremor, Am. Fam. Physician 83 (2011) 697-702 http://www.ncbi.nlm.nih.gov/pubmed/21404980 , Accessed date: 19 March 2017.

[131] R.S. Akhtar, M.B. Stern, New concepts in the early and preclinical detection of Parkinson's disease: therapeutic implications, Expert Rev. Neurother. 12 (2012) 1429-1438, https://doi.org/10.1586/ern.12.144.

[132] Y. An, L. Tang, X. Jiang, H. Chen, M. Yang, L. Jin, S. Zhang, C. Wang, W. Zhang, A photoelectrochemical immunosensor based on Au-doped TiO2 nanotube arrays for the detection of $\alpha$-synuclein, Chemistry 16 (2010) 14439-14446, https://doi.org/ 10.1002/chem.201001654.

[133] Ronan Baron, Maya Zayats, I. Willner, Dopamine-, L-DOPA-, Adrenaline-, and Noradrenaline-induced Growth of Au Nanoparticles: Assays for the Detection of Neurotransmitters and of Tyrosinase Activity, (2005), https://doi.org/10.1021/ AC048691V.

[134] E. Norrby, Prions and protein-folding diseases, J. Intern. Med. 270 (2011) 1-14 https://doi.org/10.1111/j.1365-2796.2011.02387.x.

[135] Y. Lim, C.E. Mays, Y. Kim, W.B. Titlow, C. Ryou, The inhibition of prions through blocking prion conversion by permanently charged branched polyamines of low cytotoxicity, Biomaterials 31 (2010) 2025-2033, https://doi.org/10.1016/j. biomaterials.2009.11.085.

[136] H.N. Ai Tran, F. Sousa, F. Moda, S. Mandal, M. Chanana, C. Vimercati, M. Morbin, S. Krol, F. Tagliavini, G. Legname, A novel class of potential prion drugs: preliminary in vitro and in vivo data for multilayer coated gold nanoparticles,
Nanoscale 2 (2010) 2724, https://doi.org/10.1039/c0nr00551g.

[137] F. Sousa, S. Mandal, C. Garrovo, A. Astolfo, A. Bonifacio, D. Latawiec, R.H. Menk F. Arfelli, S. Huewel, G. Legname, H.-J. Galla, S. Krol, Functionalized gold nanoparticles: a detailed in vivo multimodal microscopic brain distribution study, Nanoscale 2 (2010) 2826, https://doi.org/10.1039/c0nr00345j.

[138] J.M. McCarthy, B. Rasines Moreno, D. Filippini, H. Komber, M. Maly, M. Cernescu, B. Brutschy, D. Appelhans, M.S. Rogers, Influence of surface groups on poly(propylene imine) dendrimers antiprion activity, Biomacromolecules 14 (2013) 27-37, https://doi.org/10.1021/bm301165u.

[139] J.M. McCarthy, D. Appelhans, J. Tatzelt, M.S. Rogers, Nanomedicine for prion disease treatment, Prion 7 (2013) 198-202, https://doi.org/10.4161/pri.24431.

[140] S.J. Xiao, P.P. Hu, X.D. Wu, Y.L. Zou, L.Q. Chen, L. Peng, J. Ling, S.J. Zhen, L. Zhan, Y.F. Li, C.Z. Huang, Sensitive discrimination and detection of prion disease-associated isoform with a dual-aptamer strategy by developing a sandwich structure of magnetic microparticles and quantum dots, Anal. Chem. 82 (2010) 9736-9742, https://doi.org/10.1021/ac101865s.

[141] M. Xie, K. Luo, B.-H. Huang, S.-L. Liu, J. Hu, D. Cui, Z.-L. Zhang, G.-F. Xiao, D.W. Pang, PEG-interspersed nitrilotriacetic acid-functionalized quantum dots for site-specific labeling of prion proteins expressed on cell surfaces, Biomaterials 31 (2010) 8362-8370, https://doi.org/10.1016/j.biomaterials.2010.07.063.

[142] M.C. Kiernan, S. Vucic, B.C. Cheah, M.R. Turner, A. Eisen, O. Hardiman, J.R. Burrell, M.C. Zoing, Amyotrophic lateral sclerosis, Lancet 377 (2011) 942-955, https://doi.org/10.1016/S0140-6736(10)61156-7.

[143] M.L. Bondì, E.F. Craparo, G. Giammona, F. Drago, Brain-targeted solid lipid nanoparticles containing riluzole: preparation, characterization and biodistribution, Nanomedicine 5 (2010) 25-32, https://doi.org/10.2217/nnm.09.67.

[144] D. Bataveljić, S. Stamenković, G. Bačić, P. Andjus, Imaging cellular markers of neuroinflammation in the brain of the rat model of amyotrophic lateral sclerosis, Acta Physiol. Hung. 98 (2011) 27-31, https://doi.org/10.1556/APhysiol.98.2011. 1.4 .

[145] L. Machtoub, D. Bataveljić, P.R. Andjus, Molecular imaging of brain lipid environment of lymphocytes in amyotrophic lateral sclerosis using magnetic resonance imaging and SECARS microscopy, Physiol. Res. 60 (Suppl 1) (2011) S121-S127 http://www.ncbi.nlm.nih.gov/pubmed/21777015 , Accessed date: 17 March 2017.

[146] Y. Cho, R. Ben Borgens, Polymer and nano-technology applications for repair and reconstruction of the central nervous system, Exp. Neurol. 233 (2012) 126-144, https://doi.org/10.1016/j.expneurol.2011.09.028.

[147] S.S. Ali, J.I. Hardt, K.L. Quick, J. Sook Kim-Han, B.F. Erlanger, T. Huang, C.J. Epstein, L.L. Dugan, A biologically effective fullerene (C60) derivative with superoxide dismutase mimetic properties, Free Radic. Biol. Med. 37 (2004) 1191-1202, https://doi.org/10.1016/j.freeradbiomed.2004.07.002.

[148] M. Das, S. Patil, N. Bhargava, J.-F. Kang, L.M. Riedel, S. Seal, J.J. Hickman, Autocatalytic ceria nanoparticles offer neuroprotection to adult rat spinal cord neurons, Biomaterials 28 (2007) 1918-1925, https://doi.org/10.1016/j.biomaterials.2006. 11.036.

[149] G.-Z. Jin, M. Kim, U.S. Shin, H.-W. Kim, Neurite outgrowth of dorsal root ganglia neurons is enhanced on aligned nanofibrous biopolymer scaffold with carbon nanotube coating, Neurosci. Lett. 501 (2011) 10-14, https://doi.org/10.1016/j neulet.2011.06.023.

[150] J.-J. Liu, C.-Y. Wang, J.-G. Wang, H.-J. Ruan, C.-Y. Fan, Peripheral nerve regeneration using composite poly(lactic acid-caprolactone)/nerve growth factor conduits prepared by coaxial electrospinning, J. Biomed. Mater. Res. 96A (2011) 13-20, https://doi.org/10.1002/jbm.a.32946.

[151] M.P. Prabhakaran, L. Ghasemi-Mobarakeh, S. Ramakrishna, Electrospun composite nanofibers for tissue regeneration, J. Nanosci. Nanotechnol. 11 (2011) 3039-3057 http://www.ncbi.nlm.nih.gov/pubmed/21776670 , Accessed date: 17 March 2017.

[152] J.Y. Lee, C.A. Bashur, C.A. Milroy, L. Forciniti, A.S. Goldstein, C.E. Schmidt, Nerve growth factor-immobilized electrically conducting fibrous scaffolds for potential use in neural engineering applications, IEEE Trans. NanoBioscience 11 (2012) 15-21, https://doi.org/10.1109/TNB.2011.2159621.

[153] H.R. Kim, K. Andrieux, S. Gil, M. Taverna, H. Chacun, D. Desmaële, F. Taran, D. Georgin, P. Couvreur, Translocation of poly(ethylene glycol- co -hexadecyl) cyanoacrylate nanoparticles into rat brain endothelial cells: role of apolipoprotein in receptor-mediated endocytosis, Biomacromolecules 8 (2007) 793-799, https:// doi.org/10.1021/bm060711a.

[154] M. Mahmoudi, S. Laurent, M.A. Shokrgozar, M. Hosseinkhani, Toxicity evaluation of superparamagnetic iron oxide nanoparticles: cell "vision" versus physicochemical properties of nanoparticles, ACS Nano 5 (2011) 7263-7276, https://doi.org/ $10.1021 / \mathrm{nn} 2021088$

[155] E. Hutter, S. Boridy, S. Labrecque, M. Lalancette-Hébert, J. Kriz, F.M. Winnik, D. Maysinger, Microglial response to gold nanoparticles, ACS Nano 4 (2010) 2595-2606, https://doi.org/10.1021/nn901869f.

[156] J. Wang, P. Sun, Y. Bao, J. Liu, L. An, Cytotoxicity of single-walled carbon nanotubes on PC12 cells, Toxicol. Vitro 25 (2011) 242-250, https://doi.org/10. 1016/j.tiv.2010.11.010.

[157] L. Zhang, R. Bai, B. Li, C. Ge, J. Du, Y. Liu, L. Le Guyader, Y. Zhao, Y. Wu, S. He, Y. Ma, C. Chen, Rutile TiO2 particles exert size and surface coating dependent retention and lesions on the murine brain, Toxicol. Lett. 207 (2011) 73-81, https://doi.org/10.1016/j.toxlet.2011.08.001.

[158] G.G. Kovacs, H. Adle-Biassette, I. Milenkovic, S. Cipriani, J. van Scheppingen, E. Aronica, Linking pathways in the developing and aging brain with neurodegeneration, Neuroscience 269 (2014) 152-172, https://doi.org/10.1016/j. neuroscience.2014.03.045

[159] V. Di Marzo, N. Stella, A. Zimmer, Endocannabinoid signalling and the 
deteriorating brain, Nat. Rev. Neurosci. 16 (2015) 30-42, https://doi.org/10. 1038/nrn3876.

[160] J. Fernández-Ruiz, J. Romero, J.A. Ramos, Endocannabinoids and neurodegenerative disorders: Parkinson's disease, huntington's chorea, Alzheimer's disease, and others, Handb. Exp. Pharmacol. (2015) 233-259, https://doi.org/10.1007/ 978-3-319-20825-1_8.

[161] N. Atassi, E. Beghi, M. Blanquer, N.M. Boulis, R. Cantello, C. Caponnetto, A. Chiò, S.B. Dunnett, E.L. Feldman, A. Vescovi, L. Mazzini, C. attendees of the International Workshop on Progress in Stem Cells Research for ALS/MND, E. Bersano, S. Brajkovic, P. Car, F. De Marchi, R. Fantozzi, A. Follenzi, M. Gelati, C. Giorgi, M. Grilli, P. Guenzi, V. La Bella, G.L. Mancardi, G. Panzarasa, M. Poloni, D. Profico, V. Silani, G. Sorarù, R. Spataro, A. Stecco, A. Vercelli, Intraspinal stem cell transplantation for amyotrophic lateral sclerosis: ready for efficacy clinical trials? Cytotherapy 18 (2016) 1471-1475, https://doi.org/10.1016/j.jcyt.2016. 08.005 .

[162] E.L. Feldman, N.M. Boulis, J. Hur, K. Johe, S.B. Rutkove, T. Federici, M. Polak, J. Bordeau, S.A. Sakowski, J.D. Glass, Intraspinal neural stem cell transplantation in amyotrophic lateral sclerosis: phase 1 trial outcomes, Ann. Neurol. 75 (2014) 363-373, https://doi.org/10.1002/ana.24113.

[163] J.D. Glass, V.S. Hertzberg, N.M. Boulis, J. Riley, T. Federici, M. Polak, J. Bordeau, C. Fournier, K. Johe, T. Hazel, M. Cudkowicz, N. Atassi, L.F. Borges, S.B. Rutkove, J. Duell, P.G. Patil, S.A. Goutman, E.L. Feldman, Transplantation of spinal cord-derived neural stem cells for ALS, Neurology 87 (2016) 392-400, https:// doi.org/10.1212/WNL.0000000000002889.

[164] L. Mazzini, M. Gelati, D.C. Profico, G. Sgaravizzi, M. Projetti Pensi, G. Muzi, C. Ricciolini, L. Rota Nodari, S. Carletti, C. Giorgi, C. Spera, F. Domenico, E. Bersano, F. Petruzzelli, C. Cisari, A. Maglione, M.F. Sarnelli, A. Stecco, G. Querin, S. Masiero, R. Cantello, D. Ferrari, C. Zalfa, E. Binda, A. Visioli, D. Trombetta, A. Novelli, B. Torres, L. Bernardini, A. Carriero, P. Prandi, S. Servo, A. Cerino, V. Cima, A. Gaiani, N. Nasuelli, M. Massara, J. Glass, G. Sorarù, N.M. Boulis, A.L. Vescovi, Human neural stem cell transplantation in ALS: initial results from a phase I trial, J. Transl. Med. 13 (2015) 17, https://doi.org/10.1186/ s12967-014-0371-2.

[165] P. Korhonen, T. Malm, A.R. White, 3D human brain cell models: new frontiers in disease understanding and drug discovery for neurodegenerative diseases, Neurochem. Int. 120 (2018) 191-199, https://doi.org/10.1016/j.neuint.2018.08. 012.

[166] L.M. Herda, E. Polo, P.M. Kelly, L. Rocks, D. Hudecz, K.A. Dawson, Designing the future of nanomedicine: current barriers to targeted brain therapeutics, Eur. J. Nanomed. 6 (2014) 127-139, https://doi.org/10.1515/ejnm-2014-0022.

[167] D. Brambilla, R. Verpillot, B. Le Droumaguet, J. Nicolas, M. Taverna, J. Kóňa, B. Lettiero, S.H. Hashemi, L. De Kimpe, M. Canovi, M. Gobbi, V. Nicolas, W. Scheper, S.M. Moghimi, I. Tvaroška, P. Couvreur, K. Andrieux, PEGylated nanoparticles bind to and alter amyloid-beta peptide conformation: toward engineering of functional nanomedicines for Alzheimer's disease, ACS Nano 6 (2012) 5897-5908, https://doi.org/10.1021/nn300489k.

[168] O. Klementieva, E. Aso, D. Filippini, N. Benseny-Cases, M. Carmona, S. Juvés, D. Appelhans, J. Cladera, I. Ferrer, Effect of poly(propylene imine) glycodendrimers on $\beta$-amyloid aggregation in vitro and in APP/PS1 transgenic mice, as a model of brain amyloid deposition and Alzheimer's disease, Biomacromolecules 14 (2013) 3570-3580, https://doi.org/10.1021/bm400948z.

[169] I.M. Neelov, A. Janaszewska, B. Klajnert, M. Bryszewska, N.Z. Makova, D. Hicks, H.A. Pearson, G.P. Vlasov, M.Y. Ilyash, D.S. Vasilev, N.M. Dubrovskaya, N.L. Tumanova, I.A. Zhuravin, A.J. Turner, N.N. Nalivaeva, Molecular properties of lysine dendrimers and their interactions with $A \beta$-peptides and neuronal cells, Curr. Med. Chem. 20 (2013) 134-143 http://www.ncbi.nlm.nih.gov/pubmed/ 23033946 , Accessed date: 1 April 2017.

[170] B. Wilson, M.K. Samanta, K. Santhi, K.P.S. Kumar, M. Ramasamy, B. Suresh, et al., Chitosan nanoparticles as a new delivery system for the anti-Alzheimer drug tacrine, Nanomedicine 6 (2010) 144-152, https://doi.org/10.1016/j.nano.2009.04. 001.

[171] B. Ray, S. Bisht, A. Maitra, A. Maitra, D.K. Lahiri, Neuroprotective and neurorescue effects of a novel polymeric nanoparticle formulation of curcumin (NanoCurc ${ }^{\mathrm{TM}}$ ) in the neuronal cell culture and animal model: implications for Alzheimer's disease, J. Alzheimers. Dis. 23 (2011) 61-77, https://doi.org/10. 3233/JAD-2010-101374.

[172] S.K. Tiwari, S. Agarwal, B. Seth, A. Yadav, S. Nair, P. Bhatnagar, M. Karmakar, M. Kumari, L.K.S. Chauhan, D.K. Patel, V. Srivastava, D. Singh, S.K. Gupta, A. Tripathi, R.K. Chaturvedi, K.C. Gupta, Curcumin-loaded nanoparticles potently induce adult neurogenesis and reverse cognitive deficits in Alzheimer's disease model via canonical Wnt/ $\beta$-catenin pathway, ACS Nano 8 (2014) 76-103, https:// doi.org/10.1021/nn405077y.

[173] R. Huang, H. Ma, Y. Guo, S. Liu, Y. Kuang, K. Shao, J. Li, Y. Liu, L. Han, S. Huang, S. An, L. Ye, J. Lou, C. Jiang, Angiopep-conjugated nanoparticles for targeted longterm gene therapy of Parkinson's disease, Pharm. Res. 30 (2013) 2549-2559, https://doi.org/10.1007/s11095-013-1005-8.

[174] Shengzhuang Tang, Lynda J. Martinez, Ajit Sharma, M. Chai, Synthesis and Characterization of Water-soluble and Photostable L-DOPA Dendrimers, (2006), https://doi.org/10.1021/OL061449L.

[175] Z. Cui, P. Lockman, C. Atwood, C. Hsu, A. Gupte, D. Allen, R. Mumper, Novel -penicillamine carrying nanoparticles for metal chelation therapy in Alzheimer's and other CNS diseases, Eur. J. Pharm. Biopharm. 59 (2005) 263-272, https://doi. org/10.1016/j.ejpb.2004.07.009.

[176] G. Liu, P. Men, W. Kudo, G. Perry, M.A. Smith, Nanoparticle-chelator conjugates as inhibitors of amyloid- $\beta$ aggregation and neurotoxicity: a novel therapeutic approach for Alzheimer disease, Neurosci. Lett. 455 (2009) 187-190, https://doi. org/10.1016/j.neulet.2009.03.064.

[177] P.V. Kulkarni, C.A. Roney, P.P. Antich, F.J. Bonte, A.V. Raghu, T.M. Aminabhavi, Quinoline-n-butylcyanoacrylate-based nanoparticles for brain targeting for the diagnosis of Alzheimer's disease, Wiley Interdiscip. Rev. Nanomed. Nanobiotechnol. 2 (2010) 35-47, https://doi.org/10.1002/wnan.59.

[178] X. Wang, N. Chi, X. Tang, Preparation of estradiol chitosan nanoparticles for improving nasal absorption and brain targeting, Eur. J. Pharm. Biopharm. 70 (2008) 735-740, https://doi.org/10.1016/j.ejpb.2008.07.005.

[179] X. Gao, B. Wu, Q. Zhang, J. Chen, J. Zhu, W. Zhang, Z. Rong, H. Chen, X. Jiang, Brain delivery of vasoactive intestinal peptide enhanced with the nanoparticles conjugated with wheat germ agglutinin following intranasal administration, J. Contr. Release 121 (2007) 156-167, https://doi.org/10.1016/j.jconrel.2007.05. 026.

[180] B. Wilson, M. Samanta, K. Santhi, K. Kumar, N. Paramakrishnan, B. Suresh, Targeted delivery of tacrine into the brain with polysorbate 80 -coated poly(nbutylcyanoacrylate) nanoparticles, Eur. J. Pharm. Biopharm. 70 (2008) 75-84, https://doi.org/10.1016/j.ejpb.2008.03.009.

[181] T. Siegemund, B.-R. Paulke, H. Schmiedel, N. Bordag, A. Hoffmann, T. Harkany, H. Tanila, J. Kacza, W. Härtig, Thioflavins released from nanoparticles target fibrillar amyloid $\beta$ in the hippocampus of APP/PS1 transgenic mice, Int. J. Dev. Neurosci. 24 (2006) 195-201, https://doi.org/10.1016/j.ijdevneu.2005.11.012.

[182] B. Wilson, M.K. Samanta, K. Santhi, K.P.S. Kumar, N. Paramakrishnan, B. Suresh, Poly(n-butylcyanoacrylate) nanoparticles coated with polysorbate 80 for the targeted delivery of rivastigmine into the brain to treat Alzheimer's disease, Brain Res. 1200 (2008) 159-168, https://doi.org/10.1016/j.brainres.2008.01.039.

[183] E. Araya, I. Olmedo, N.G. Bastus, S. Guerrero, V.F. Puntes, E. Giralt, M.J. Kogan, Gold nanoparticles and microwave irradiation inhibit beta-amyloid amyloidogenesis, Nanoscale Res. Lett. 3 (2008) 435-443, https://doi.org/10.1007/s11671008-9178-5.

[184] S.R. Schaffazick, I.R. Siqueira, A.S. Badejo, D.S. Jornada, A.R. Pohlmann, C.A. Netto, S.S. Guterres, Incorporation in polymeric nanocapsules improves the antioxidant effect of melatonin against lipid peroxidation in mice brain and liver, Eur. J. Pharm. Biopharm. 69 (2008) 64-71, https://doi.org/10.1016/j.ejpb.2007. 11.010.

[185] Z. Songjiang, W. Lixiang, Amyloid-beta associated with chitosan nano-carrier has favorable immunogenicity and permeates the BBB, AAPS PharmSciTech 10 (2009) 900-905, https://doi.org/10.1208/s12249-009-9279-1. 